\title{
ETIOUETA Y CEREMonial PALATINO DURANTE EI. REINADO DE FELIPE V: EL REGLAMENTO DE ENTRADAS DE 1709 Y EL ACCESO A LA PERSONA DEL REY
}

por

CARLOS GÓMEZ-CENTURIÓN JIMÉNEZ

Universidad Complutense de Madrid

\begin{abstract}
"La conducta de los reyes y y de las reinas de España está reglamentada de tal forma por lo que se denomina la Etiqueta de Palacio. que no hay más que leerla para saber en qué se han ocupado todos los reyes de España desde Felipe II y lo que harán los sucesores de Carlos II hasta el dia del Juicio Final»
\end{abstract}

Claude Jordan (1693)

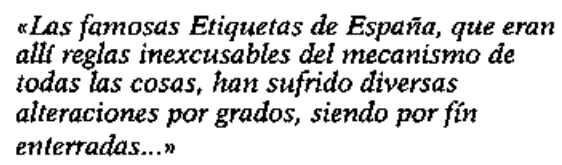

Duque de Saint-Simon (1722)

RESUMEN: Bajo la aparente continuidad de las plantas de criados de las casas reales y de los libros de etiquetas que regian su funcionamiento, el ceremonial real experimentó importantes transformaciones a lo largo del siglo XVIJ. El nuevo reglamento de entradas al cuarto del rey decretado en 1709, asi como su puesta en vigor -estudiados en el presente articulo- constituyen un buen ejemplo de cuán ambiguas y contadictorias fueron las fuerzas que impulsaron los cambios en la vida de la corte madrileña durante el reinado de Felipe V. Diseñado a imitación del de Versalles para restar autoridad y protagonismo a los altos oficiales de la Casa del Rey y hacer brillar la majestad del soberano, su puesta en vigor fracasó a causa del desequilibrio mental de Felipe $V$, aferrado a los criados y las normas de su antigua casa de duque $D$ Anjou. Ello supuso una grave crisis para los cargos más emblemáticos de la Casa del Rey, y una subversión de las reglas que durante un siglo y medio

1 JoRdan, C., Voiages historiques de l'Europe, París, 1693, t. II, págs. 39-40; SAINF-Simón, Duque de, Cuadro de la Corte de España en 1722, (ed. esp.), Madrid, 1933, pág. 22. 
habian regulado el acceso a la persona del monarca, criterio clave que regía la economía de poder en la corte y las estrategias de actuación de los cortesanos.

Palabras clave. España, siglos xvi y xviI, Corte, Casa Real, Ceremonial Real, Etiquetas, Acceso al rey, Gracia real, Nobleza cortesana, Felipe $\mathrm{V}$ de Borbón.

ABSTRACT: During the I8th century, royal ceremonials underwent a significant transformation, despite the apparent lack of changes in both the number of ser. vants in the Royal Household and in the books of etiquette that ruled its functioning. This article focuses on the new regulations of 1709 concerning access to the King's chamber. These new rules are a good indication of the contradictory and ambiguous nature of the forces that brought about the changes in Madrid's court life during the reign of Philip V. Designed as a reponse to the Versailles code, these rules attempted to limit the traditional authority and protagonism held by the high officials of the Royal House and to enhance the majesty of the king. However, these regulations were never succesfully enforced due to the mental inestability of King Philip who refused to renounce his loyalty to his longtime servants, and insisted on maintaining the traditional norms which accompained his former position as Duke D'Anjou. The King's reaction provoked a profound crisis among the most emblematic positions within the Royal Household, as well as a subversion of the norms that had regulated access to the monarch during the last 150 years, an alteration that would impact the distibution of the economy of power within the court and the strategies of action of the courtiers.

Key words: Spain, Court, Royal Household, Royal Ceremonials, Etiquette, King' access, Royal Favour, Courtly nobility, Philip V of Bourbon.

\section{INTRODUCción}

Aunque el tema de la Corte, desde sus diversos prismas, esté cada día más presente en la historiografía modernista española, una de sus instituciones centrales, la Casa Real, carece en cambio hasta la fecha de monografías de base que expliquen correctamente su estructura, funcionamiento y evolución. Algo mejor conocido el periodo de la dinastía de los Habsburgo - durante el cual el servicio y el ceremonial reales cristalizan en sus rasgos más característicos ${ }^{2}-$, su

2 Para la organización de la Casa Real durante los siglos xvl y xvlt, entre las obras clásicas, debe citarse a RodrlGuez Villa, A., Etiquetas de la Casa de Austria, Madrid, 1913 -cuyo trabajo va más poco más allá de la publicación fragmentaria de las Etiquetas de 1651 -, así como el discurso de DE LA VALGOMA, y DiAZ VARELA, Dalmiro, Norma y ceremonia de las reinas de la Casa de Austria, Madrid, 1958, que proporciona algunos datos interesantes. Nueva información, también basada en los libros de etiquetas, en HoFMANN, Ch., Das Spanische Hofzeremoniell von 1500-1700, Frankfurt, 1985. Referente a las etiquetas de la Real Cámara, el artículo de BotTINEAU, Y: «Aspects

Hispania, LV]/3, núm. 194 (1996) 965-1005 
evolución durante el siglo xvIn, por el contrario, apenas ha recibido atención por parte de los especialistas 3 .

Aparentemente, se produjeron pocos cambios en la estructura y organización de la Casa Real -o de las Casas Reales, para ser más precisos-a lo largo del siglo XviI. La llegada de la dinastía borbónica, con una concepción del absolutismo real más acentuada y nuevos criterios organizativos en torno a la administración de la Monarquía no implicó, sin embargo, una transformación demasiado drástica en la organización de los servicios palatinos o del ceremonial real, Aunque en los primeros años del reinado de Felipe V se barajaran varios proyectos para modificar completamente el entramado de las Casas Reales, adaptándolo al nuevo modelo francés de Versalles, diversos criterios de oportunidad política desaconsejaron emprender cambios tan drásticos. La necesidad de subrrayar la continuidad dinástica durante la Guerra de Sucesión, la conveniencia de no provocar grandes quiebras en la fidelidad de los clanes nobiliarios, o la imposibilidad de romper todo el entretejido de intereses creados en torno a la vida del palacio fueron elementos que hubieron de

de la Cour d'Espagne au Xvo" siècle: l'étiquette de la chambre du rois, en Bulletin Hispanique, LXXIV (1972), págs. 138-157. Para el periodo de tránsito hacia el ceremonial borgonón es útil DOMinguez CASAS, R., Arte y etiqúeta de los Reyes Católicos, Madrid, 1993. Aspectos generales del ceremonial de los Habsburgo en Lisón Tolosana, C., La imagen del rey, Madrid, 1992. Por lo que respecta al reinado de Felipe II, el trabajo de PFANDL, L., «Philip II und die Einfhührung des burgundischen Hofzeremoniells in Spanien», en Historisches Jahrbuch, 58 (1938), págs. 1-33, va siendo superado por trabajos posteriores: Rodríguez SALGADO, M., "The Court of Philip ll of Spain», en Asch, R.G., y BIRKE, A.M. (eds.), Princes, Patronage and the Nobility. The court at the Beginning of the Moderna Age, Oxford U.P., 1991, págs. 205-244; y el reciente volúmen colectivo de MarTínez Millán, J., (dir.), La corte de Felipe II, Madrid, 1994. Para el siglo xvil resultan indispensables los trabajos de ElLIorT, J. H.: «Philip IV of Spain», en A. G. Dickens (ed.), The Courts of Europe, Londres, 1977, Cap. 8; «The Court of the Spanish Habsburgs: a peculiar institution?", en Politics and Culture in Early Modern Europe. Essays in Honour of H. G. Koenigberger, eds. por MACX, P. y JACOB, M. C., Londres, 1986 (trad. esp. en España y su mundo, 1500-1700, Madrid, 1990, Cap. 7) y Un palacio para el rey, (ed. esp. Madrid, 1981) fruto de su colaboración con BRowN, J.

3 En comparación, el siglo xvill está prácticamente desatendido. Aunque desde la perspectiva de la histotia del arte, el trabajo de BotTiNEAU, Y., El arte cortesano en la España de Felipe V (I7001746) (ed. esp.), Madrid, 1986, resulta de una gran utilidad, especialmente por el trabajo que realiza sobre las fuentes francesas de comienzos del reinado, pero es menos exhaustivo en la consulta de fuentes relativas a la Casa Real en el Archivo General de Palacio. Ideas sugerentes sobre la evolución de algunos aspectos del ceremonial real en VARELA, J., La muerte del rey, Madrid, 1990. El libro de Lolo, B., La música en la Real Capilla de Madrid: José Torres y Martinez Bravo (h. 1670-1738), Univ. Autónoma de Madrid, 1990, incluye un capítulo de gran utilidad sobre la organización y el funcionamiento de la Real Capilla del palacio madrileño. El trabajo de Rodriguez GrL, M., La nueva planta de la Real Casa...Los oficios de Contralor y Grefier General, Madrid, 1989 aporta datos útiles para la evolución de estos dos oficios, pero es mucho más confuso respecto a la organización general de la Casa Real. También son de interés las aportaciones del administrativista MENÉNDEZ REXACH, A., La Jefatura del Estado en el Derecho público español, Madrid, 1979, concretamente las págs. 455-504, dedicadas al régimen jurídico de los servicios de apoyo de la Jefatura del Estado en España, desde 1717 en adelante. Del mismo autor vid. «La separación entre la Casa del Rey y la Administración del Estado (1814-1820)», en Revista de Estudios Politicos, 55 (1987), págs. 55-121. 
pesar mucho a la hora de reorganizar el servicio y el ceremonial reales. De hecho, las sucesivas reformas emprendidas a lo largo del siglo por los equipos ilustrados, tratando de racionalizar y burocratizar la Casa Real, toparon con numerosas dificultades frente a una institución tan peculiar como ésta y tan aferrada a hábitos de conducta tradicionales.

Ello no quiere decir que la institución permaneciera inmóvil durante más de cien años. Bajo la superficie glacial y aparentemente inmutable del ceremonial cortesano, se produjeron transformaciones muy importantes, suscitadas al calor de los nuevos tiempos y de los nuevos hombres que dirigian los rumbos de la Monarquía. El que se mantuvieran hasta fechas muy tardías casi intactas la estructura de las antiguas Casas Reales y -pese algunos retoques- sus plantas de criados, o el que las etiquetas de Felipe IV, que debían regir su funcionamiento, se siguieran copiando y utilizando como guía de cortesanos no deben inducirnos a engaño. Bajo esta apariencia de continuidad, se produjeron cambios importantes que es aún preciso determinar e interpretar. Pero a falta de bruscas y drásticas reformas, se hace necesaria una laboriosa tarea de investigación que rastree en el día a día del funcionamiento de la institución los cambios operados mediante pequeñas -pero continuasdisposiciones, introduciendo novedades u omitiendo el cumplimiento de otras antiguas. Tal es la intención de este trabajo que pretende determinar cómo se transformó, durante el reinado de Felipe V, el antiguo ceremonial que regulaba en palacio las entradas a la Cámara del monarca y el acceso a la persona del rey ${ }^{4}$.

\section{LA REFORMA DE LA CÁMARA DEL REY (1701)}

Reformar la Casa del rey difunto, Carlos II, constituyó una de las principales preocupaciones de las cortes de Versalles y de Madrid en vísperas de la llegada de Felipe V a España. Si para Luis XIV escoger cuidadosamente el círculo de personas que habría de rodear a su nieto constituía un requisito indispensable para asegurar con éxito la instalación de la nueva dinastía en la corte madrileña, para el partido pro-francés de ésta, encabezado por el cardenal Portocarrero, aquella medida suponía garantizar su hegemonía y apartar del escenario político a muchos peligrosos competidores.

Precisamente a los pocos días de fallecer Carlos II y antes de su salida de Madrid, el embajador francés, el duque de Harcourt, había encargado a Porto-

4 El presente trabajo constituye una primera $-y$ provisional- aportación de un vasto proyecto de investigación que, dirigido por el profesor Feliciano Barrios Pintado y por mí mismo, pretende estudiar La Casa Real española durante la Edad Moderna, con financiación de la DGICYT, PB930652-C02-02/93. Por motivos de espacio ha sido imposible incluir referencias acerca de todos y cada uno de los cargos de la Real Casa que se mencionan, así como a detalles de la organización administrativa y económica del servicio real, que serán objeto de próximos estudios particulares; vid. Gómez-CEnTURIón, C. y SÁNCHez BelÉn, Juan, "La Casa Real en el siglo xvil: perspectivas para su estudion, en CaStezlanos, J. L. (ed.), Sociedad, administración y poder en la España del Antiguo Régimen, Univ. de Granada, 1996, págs. 155-174.

Hispania, LVI/3, núm. 194 (1996) 965-1005 
carrero el diseño de la nueva Casa del Rey, indicándole que debía reducirla «al menor número que se pueda y a las personas más honestas, a fin de que (su Majestad Católica) no se vea asediada por esa gran cantidad de oficiales, entre todos los cuales habria muchos que tratarian de hacerse dueños de su voluntadn. Dfas más tarde, su sustituto expresaba los mismos temores acerca de que "la mayor parte de los señores que encontraron gusto en ser como pequeños reyes durante el anterior reinado, traten de torcer la voluntad del nuevo Rey para vivir de la misma forman ${ }^{5}$.

Reformar un universo tan aparentemente inmóvil y arraigado como era el de la Real Casa, sin embargo, no constituía una empresa fácil de acometer pues, incluso en épocas críticas de cambio político, un relevo completo de sus oficiales resultaba impensable. Veamos un ejemplo. En 1644 una Junta de Reformación encargada de estudiar la vieja Casa de Castilla había aconsejado al rey suprimirla en vista de su coste y de que a aquellos criados prácticamente sólo les quedaba "el nombre» de sus cargos, pero no el servicio. Felipe IV respondió a la consulta de la Junta enumerando toda una serie de razones para no aprobar la medida, aunque la reducción de gastos le pareciese necesaria: el rey no debia, «por resoluciones ni ordenes mías, descaradamente» alterar de una forma tan drástica el "uso antiguo" de las Casas Reales; tampoco podía despojar arbitrariamente de mercedes y recompensas a quienes en justicia gozaban aquellos cargos como premio a sus servicios, ni privar del necesario sustento a cuantos servidores pudieran depender de él ${ }^{5}$. Esta curiosa consulta nos pone, por boca del mismo monarca, en la pista de las diversas funciones que cumplía la Casa Real: $1 .^{2}$ ) Debía proveer al soberano de un marco adecuado en donde resaltar la majestad real; más que una función estríctamente práctica y doméstica, cumplía entonces con una función simbólica de primer orden, ligada estrechamente a la dinastía y sostenida por la tradición; $2^{a}$ ) este prestigio de la majestad real se comunicaba, en diferentes grados, a quienes servían de cerca al soberano y que, precisamente por su proximidad a la persona del rey, eran también los acreedores más próximos a la gracia real y beneficiarios de sus recompensas; $3{ }^{2}$ ) por último, constituía una gran bolsa de cargos, mercedes y pensiones en torno a la cual era posible fomentar fidelidades, concertar alianzas y aunar cientos de intereses contrapuestos, poniéndolos al servicio de la monarquía.

La Casa Real constituía, entonces, un hervidero de intereses creados, de alianzas sociales y familiares, de intrigas politicas, cuyo difícil equilibrio no siempre podía ser controlado enteramente por el soberano, y que entraba en época de máximas tensiones e inestabilidad en cada relevo gubernamental o, con frecuencia, en cada cambio de reinado. Pero sus transformaciones solían ser lentas o, en todo caso, realizadas con un gran pulso político.

5 Cit. por Bottineau, Y., El arte cortesano..., pág. 157. Ver asimismo Marqués de LouviLLe, Mémoires secrets sur l'établissement de la Maison de Bourbon en Espagne. Extraits de la correspondance du... gentilhomme de la Chambre de Philippe Vet Chef de la Maison française, (ed. conde S. du Roure), 2 vols., Paris, 1818.

6 (A)rchivo (G)eneral de (P)alacio, Administrativa, leg. 340.

Hixpania, LVI/3, núm. 194 (1996) 965-1005 
La prisas del cardenal Portocarrero por publicar los decretos de reforma de la Casa del Rey, asegurándose con ello el control del palacio madrileño, toparon con la prudencia de Versalles, muy consciente de los inconvenientes políticos de semejante precipitación. Luis XIV, primero, y el embajador Harcourt, después, detuvieron la iniciativa del cardenal hasta la llegada de Felipe V a Madrid. Se debía dar la impresión de respetar la voluntad testamentaria de Carlos II respecto al mantenimimiento de sus antiguos servidores, en tanto que el nuevo soberano pudiera "conocer por sí mismo el mérito de los oficiales de su casa, antes de concederles gracias que dependen únicamente de ét" ${ }^{7}$. Sin embargo, el diseño de las principales transformaciones estaba ya decidido, y la opinión de la corte nunca se engañó repecto a la responsabilidad que le había cabido a Portocarrero en la reforma ${ }^{8}$.

Dos puntos preocupaban especialmente a la corte Versalles con respecto a la Casa del Rey de España y sus etiquetas: la excesiva invisibilidad del monarca -que Luis XIV consideraba un comportamiento indigno, más característico de un soberano oriental que de un príncipe de la Casa de Francia- y, ligada a esta invisibilidad, la reclusión de la persona del rey vigilada por los grandes, que mermaba su autoridad en palacio y su independencia?.

Por ello, aparte del nombramiento de nuevos jefes para la Casa y la Caballeriza del Rey -el marqués de Villafranca como Mayordomo Mayor y el duque de Medina Sidonia como Caballerizo y Montero Mayor-, toda la atención se centró en la Real Cámara, cuyo personal debía constituir el entorno más próximo y cotidiano para el soberano. A cargo de los aposentos privados del monarca y de su servicio más personal, aunque concebida como un departamento más de la Casa del Rey, la Real Cámara llevaba casi un siglo, al amparo de sus importantes funciones, inmersa en un proceso de paulatina independencia respecto a la jurisdicción del Mayordomo Mayor y de la Junta del Bureo ${ }^{10}$, que habían dirigido sus propios oficiales ". Encabezada por el Camarero Mayor, este cargo se había dejado de proveer desde el reinado de Carlos V para evitar, precisamente, problemas de rango y autoridad con el Mayordomo Mayor ${ }^{12}$. Desde entonces,

7 BoTTINEAU, Y., op. cit., págs. 156 y 161. Las disposiciones testamentarias del último de los Austrias referentes a los criados y of iciales de su casa pueden consultarse en Testamentos de los Reyes de la Casa de Austria (ed. facsimil), Madrid, 1982.

${ }^{8}$ "...todo lo ejecutaba para acreditarse celante y estrechar, cuanto era posible, al Rey a que tratase con pocos , BaCALlaR y SANNA, V., Marqués de San Felipe, Comentarios a la guerra de España e historia de su rey Felipe V, el Animoso, B.A.E., t. XCIX, Madrid, 1957 (introducción y notas de C. Seco Serrano), pág. 17.

9 Se han hecho célebres los comentarios realizados por Luis XIV a este respecto en sus Memorias (ed. esp.), México, 1988, págs. 96-97. Ver asimismo BURKE, P., The Fabrication of Louis XIV, Yale University Press, 1992, pág. 184.

10 Acerca de esta Junta, vid. DE Benito, Emilio, «La Real Junta del Bureo», en Cuadernos de Historia del Derecho, núm. 1 (1994), págs. 49-124.

11 Sobre este proceso pueden consultarse, A. G. P., Histórica, c. ${ }^{a}$. 49; Luis I, c. ${ }^{a}, 1$; Felipe V, legs. 313 y 459 ; Administrativa, leg. 929.

12 El Camarero Mayor era el oficial de mayor rango en la casa de los Duques de Borgoña, no asi en el ceremonial castellano, vid. PARAVICINI, W., «The Court of the Dukes of Burgundy: A Model for Europe?», en R. G. Asch y A. M. Birke (eds.), op, cit., págs. 69-102.

Hispania, LV1/3, núm. 194 (1996) 965-1005 
sus funciones venían siendo desempeñadas por su asistente, el Sumiller de Corps, quien, a pesar de todo, había cobrado en la vida de palacio un protagonismo cada día mayor debido a su estrecho y cotidiano contacto con el monarca, al que levantaba y vestía por las mañanas, y en cuya alcoba podía incluso dormir. Al Sumiller de Corps le correspondía, además, el cuidado de los habitaciones privadas del rey, tomar juramento a todos los criados de la Cámara -sobre los que tenía jurisdicción-, y administrar todas las consignaciones que correspondiesen a su departamento, incluido el Bolsillo Secreto. Debido a su capacidad de influencia personal sobre el monarca, el cargo de Sumiller de Corps se había convertido en el más ambicionado de todas las Casas Reales, siendo frecuentemente desempeñado por los validos de la centuria anterior ${ }^{13}$.

Igualmente codiciados por la nobleza eran los cargos de Gentileshombres de Cámara que deb́an auxiliar al Sumiller en sus tareas. Existían tres grados distintos: los de ejercicio, los de entrada y los honoríficos. Todos podían llevar como distintivo de su dignidad una gran llave en la cintura con el mango dorado. Pero sólo los dos primeros grados tenían acceso libre al cuarto del rey, y únicamente los de ejercicio servían de forma efectiva a la persona del monarca. Por eso también sólo sus llaves podían abrir y cerrar las cerraduras del palacio, mientras el resto eran caponas ${ }^{14}$. De guardia permanente en las habitaciones del rey, y acompañándole en todas las funciones públicas, nada podía llegar a las manos o a los oidos del soberano sin pasar antes por el intermedio del Sumiller de Corps o los Gentileshombres de Cámara.

Jerárquicamente por debajo de éstos se situaban los Ayudas de Cámara y los oficiales del Guardarropa, así como médicos, cirujanos y barberos, el personal de la Real Botica, los oficiales de manos, etc., que completaban el servicio personal del rey. Del Sumiller de Corps dependían asimismo el Secretario de la Cámara y de la Estampilla y sus oficiales, que actuaban como secretarios personales del monarca atendiendo el despacho de papeles en el bufete real, organizando las audiencias, etc ${ }^{15}$.

Confirmado en el cargo de Sumiller de Corps en 1701 el que lo fuera a la muerte de Carlos II, el duque de Benavente, mucho más delicado era el nombramiento de Gentileshombres y Ayudas de Cámara, cuyo número se había disparado durante el reinado anterior. Aunque la Junta de Gobierno ordenara que los titulares conservaran sus llaves, según lo dispuesto por Carlos II en su testamento ${ }^{16}$, Versalles juzgaba estrafalaria la cifra de 32 Gentileshombres de servicio y 33 Ayudas de Cámara, por lo que su reducción parecía inevitable ${ }^{17}$.

13 Acerca de cómo era valorada la superioridad efectiva de este cargo veanse los comentarios del Duque de Saint-Simon, Cuadro..., págs. 211-212 y 229-234.

14 Sobre los incidentes que provocaban las pérdidas de estas llaves, A. G. P., Felipe V, legs. 313 y 314 .

is Una descripción más completa de la funciones de cada uno de estos oficiales de la Real Cámara en su Reglamento de 1649 , (B)iblioteca (N)acional de (M)adrid, mss. 4313. Y. BotTinEAU transcribe parte de él en "Aspects de la cour d'Espagne...», págs. 138-157.

16 A. G. P., Felipe V, leg. 311.

17 BotTINEAU, Y., El arte cortesano..., pág. 156. 
Recién llegado Felipe V a Madrid, fueron nuevamente nombrados sólo seis Gentileshombres de Cámara con ejercicio, reservandóle a los demás su derecho de entrada, y limitados a 12 los Ayudas de Cámara ${ }^{18}$. Igualmente, fueron reducidos a la mitad los otros dos cortejos nobiliarios de la Real Casa, los Gentileshombres de la Boca y de la Casa - de mucha menor influencia que los de la Cámara-quedando respectívamente en 12 y $10^{19}$.

Como complemento a esta reducción de cargos, se nombraron para la Cámara del rey varios de los oficiales franceses que habian viajado con Felipe V desde Versalles: Claude de La Roche como Secretario de la Cámara y de la Estampilla, Gaspard Hersant como Jefe del Guardarropa, Honoré Michelet como primer Médico, Jean Baptiste Legendre, primer Cirujano, Louis Riqueur, Jefe de la Botica, Henri Vazet, Barbero y Peluquero de Corps... ${ }^{20}$.

El resto, en su mayoría mozos de cámara y guardarropa, oficiales de boca y criados de las caballerizas, formaron con carácter provisional una Familia francesa aparte de la española, creada para facilitar la adaptación de Felipe $V$ en sus primeros tiempos en Madrid, pero de la cual el monarca ya nunca sabría desprenderse ${ }^{21}$.

Mas no era sólo la titularidad de los altos cargos de la casa de su nieto lo que preocupaba a Luis XIV, sino, sobre todo, las etiquetas que fijaban sus funciones y prerrogativas y les concedían una autoridad en el Alcázar de Madrid impensable entonces en el palacio de Versalles. Mucho se ha escrito ya sobre la diferente concepción en cuanto a los modos de representar la majestad real que tuvieron las cortes de Carlos II y Luis XIV ${ }^{22}$. Recientemente, Burke dudaba con sensatez de que tales diferencias fueran demasiado profundas, habida cuenta de que el propio Luis XIV - menos accesible y menos visible que su inmediato antecesor- debió tener una deuda de aprendizaje importante contraída con el ceremonial español ${ }^{23}$. Pero más allá de las diferencias externas y visuales, se escondian condiciones políticas diferentes con respecto a la posición del soberano y de sus noblezas respectivas. Si la corte de Carlos II había ofrecido hacia el exterior la impresión de albergar un soberano "prisionero de la oligarquía y refugiado tras la barrera del protocolon, tal efecto no era resultado tanto del ceremonial habsburgo-borgoñón en sí mismo, sino de la falta de control por parte del monarca español de unas etiquetas que sus antepasados habían utilizado, magistralmente en ocasiones, para elevar y magnificar la figura del rey: "las ceremonias y las etiquetas de la corte -indicaba el profesor Elliott hace años-, aprentemente tan uniformes e invariables, podían ser utilizadas con diferentes efectos en diferentes reinados, de acuerdo con la cambiante personalidad del monarca" ${ }^{24}$. Claro que el aisla-

\footnotetext{
18 A. G. P., Felipe V, legs. 311 y 330.

19 A. G. P., Felipe V, leg. 18.

20 A. G. P., Felipe V, leg. $31 \mathrm{t}$.

21 A. G. P., Histórica, c.". 125.

22 Interesantes puntos de vista en Morá, M., La imagen del rey. Felipe Vy el arte, Madrid, 1990.

23 BURKe, P., op. cit., págs. 180-185.

24 ELLıot, J. H., España y su mundo, 1500-1700, págs. 199 y 176.
} 
miento del rey como figura remota, tan sólo visible la mayor parte del tiempo para un escaso número de privilegiados - tal y como se había consolidado en el ceremonial español- ofrecía particulares peligros. La vida del palacio madrileño concedía un puesto privilegiado para la nobleza y los grandes que - tal y como observara el duque de Saint-Simon- "son dondequiera el acompañamiento del rey y su más natural y más ilustre cortejo" "25. Para ellos se reservaban la mayoría de los altos cargos de palacio y los puestos de honor en todas las ceremonias públicas de la realeza. Sin un claro dominio de este entorno por parte del monarca, los derechos y privilegios de los cortesanos, que tan meticulosamente regularan las etiquetas codificadas por Felipe IV, podían acabar fácilmente imponiéndose sobre el mismo soberano ${ }^{26}$. Así parece haber ocurrido durante el difícil reinado de Carlos II, a lo largo del cual la nobleza y los grandes habían consolidado su posición en palacio y en el aparato administritativo de la Monarquía, copando a un tiempo los salones regios y las dependencias burocráticas del Alcázar de Madrid.

Pero transformar drásticamente las etiquetas de la corte española, lo mismo que su maquinaria administrativa, constituían para Versalles, a todas luces, un objetivo políticamente inalcanzable durante los meses que siguieron a la aceptación del testamento de Carlos ${ }{ }^{27}$, por mucho que se sospechara que, con el mantenimiento de éstas, los grandes aspiraban a "mantener al rey reclufdo, excepto para ellos" ${ }^{28}$. Luis XIV debía conformarse, entonces, con que su nieto, rodeado de los consejeros adecuados, intentase de restaurar la autoridad real en palacio y, con el paso del tiempo, se fuese modificando favorablemente la situación.

$\mathrm{Si}$ bien durante su viaje hasta la frontera española, Felipe $\mathrm{V}$ fue servido como un príncipe de la Casa de Francia, impidiendo que los nobles españoles que le acompañaran pudieran ejercer cerca de él las funciones que les hubieran correspondido en Madrid ${ }^{29}$, a su llegada a la corte no pudo eludir más cumplir con algunas obligaciones del ceremonial español. Se decidió que el joven monarca visitaría por las mañanas las piezas del Alcázar donde se reunían los grandes y el resto de la corte ${ }^{30}$, y se señalaron dos días en semana para las audiencias públicas que, como contrapunto obligado a su escasa visibilidad cotidiana, los monarcas españoles venían concediendo, respetando así la tradición de los duques de Borgoña ${ }^{31}$. La inminente jornada de Cataluña

2s SAINT-Simon, Duque de, Memoires, Ed. Gallimard, 1953, t.I., pág. 1023.

26 Sobre este proceso siguen siendo fundamentales las observaciones de ELIAS, N., en La sociedad cortesana, México, 1982, págs. 107-158, asi como las sugerencias de GIESEY, R. E., «La société de coury, en Cérémonial et puissance souveraine. France, $\mathrm{XV}^{\circ}$-Xvır siècles, París, 1987; págs. 67-86.

27 Todavia más fantástica parece la propuesta del marqués de Villena, cargada de significación política, de que la monarquía retornase al viejo ceremonial real castejlano anterior a los Habsburgo, vid. BotTINEAU, Y., op. cit. pág. 143.

${ }^{28}$ Ibidem, pág. 207.

29 Ibidem, pág. 153.

30 lbidem, pág. 207.

31 A. G. P., Administrativa, leg. 37. 
dejaría en suspenso, sin embargo, muchas de las decisiones que cabía tomar acerca de la vida que el nuevo soberano habría de llevar en sus palacios de Madrid.

\section{EN TORNO A UN PUNTO DE ETIQUETA (1703)}

No fue, lógicamente, hasta la vuelta de Felipe $\mathrm{V}$ a la corte, en enero de 1703 , cuando comenzaron a plantearse los primeros problemas serios. $\mathrm{La}$ vida del rey hasta entonces, en especial durante los meses siguientes a su llegada, se había revestido de un cierto carácter provisional, de necesario ajuste y adaptación que, en medio del marasmo político, apenas habra provocado grandes incidentes ${ }^{32}$. La jornada de Cataluña, primero, y la de Italia, después, sólo habían contribuído a aumentar esta sensación de urgencia y provisionalidad que venía rodeando al servicio del monarca y, aún por aquellas fechas, ninguna innovación podía considerarse todavía definitva ${ }^{33}$.

Una cuestión fundamental, el acceso a la persona del rey y su regulación - con todo lo que ello implicaba-, se iba a convertir en el caballo de batalla de los cortesanos madrileños durante los años siguientes, habiendo de enfrentarse a una situación de facto impuesta por los consejeros franceses del monarca que apenas se ajustaba a las normas tradicionales del ceremonial español.

Uno de los primeros incidentes serios que han quedado documentados acerca del problema del acceso a las habitaciones reales tuvo como protagonista al Nuncio papal, el arzobispo de Larisa, a comienzos de 1703, y puso sobre el tapete de la corte la necesidad ineludible de regular adecuadamente la cuestión de las entradas al palacio y a la cámara del rey. El suceso había tenido lugar el Sábado de Pentecostes. En Nuncio y el embajador de Saboya, por entonces los únicos embajadores católicos acreditados en la Corte, habían acudido al Buen Retiro, como venía siendo tradicional, para acompañar al soberano en la función de Capilla que debía tener lugar con motivo de aquella festividad religiosa. Las Capillas públicas, $\tan$ frecuentes en el ceremonial de palacio durante la centuria anterior, habían tenido un carácter mucho más esporádico desde el acceso al trono de Felipe V, y únicamente se había celebrado otra función igual en el Retiro el 8 de mayo de 1701. Al ir al encuentro del monarca, ambos diplomáticos fueron detenidos por el conduc-

32 Todas las memorias e informes politicos de aquellos meses están trufados de anécdotas relativas a pequentos incidentes sucedidos en el entorno del rey por motivos de protocolo y ceremonial. En general, los cortesanos españoles vieron con desagrado buena parte de las innovaciones introducidas en el servicio del monarca y se resistieron a los usos franceses. La exclamación de protesta del marqués de Villafranca, Mayordomo Mayor del rey de que «en España estamos y es necesario hacer las cosas como en España se hacen» constituye por sí misma todo un manifiesto castizo, vid. Coxe, W. España bajo el reinado de la Casa de Borbón (ed. esp. de J. Salas y Quiroga), Madrid, 1846, t.I, págs. 102-104.

33 Algunos detalles en BottineAu, Y., op. cit., págs. 194-200.

Hisponia, LVI/3, núm. 194 (1996) 965-1005 
tor de embajadores, y apercibidos en nombre del soberano para que no entrasen más allá de la pieza inmediata a la de las Audiencias, que era la que correspondía a los representantes extranjeros. La misma amonestación por escrito fue recibida en las respectivas legaciones a los pocos días, y ambos diplomáticos decidieron de mutuo acuerdo que fuera el Nuncio quien respondiera oficialmente en nombre de los dos.

La contestacion del arzobispo de Larisa al conductor de embajadores nos interesa porque es, a la vez que una disculpa protocolaria, un firme alegato de defensa de los derechos y prerrogativas que las etiquetas palatinas reservaban para los representates de príncipes extranjeros ${ }^{34}$. El Nuncio se excusaba alegando que si "el señor embaxador de Saboya y yo nos detuvimos unas piezas más adentro a esperar que saliese su Majestad, esto fue porque no se sabia cuál era la pieza que su Majestad habia señalado para este efecto, pues no podíamos arreglarnos con lo que antes se practicaba, a causa que mucho más adelante que la misma pieza que ahora se señala se veian pasar gentes que, según las costumbres de la corte, no podían pasar más adelante de la Pieza de los Embaxadores». El problema entonces, según el Arzobispo, radicaba en la inobservancia de las etiquetas que tradicionalmente habian regulado el tránsito por las distintas habitaciones de palacio, ya que sólo aquel desorden podía haberles llevado a ellos mismos a incurrir en el error de traspasar la pieza que les estaba asignada: «y esta no fue imaginación sin fundamento, pues bien lo vio vuestra Señorí estando con nosotros en la pieza que su Majestad tiene señalada el domingo inmediato (a) Pascua de Pentecostes por la mañana, que a mi no me conviene referir por individuos". El Nuncio expresaba, no obstante, su más rendida conformidad con las disposiciones del Rey Católico, aceptando el libre señalamiento por su parte del lugar que les correspondiese a los embajadores ocupar, tanto en el Buen Retiro como en cualquier otro palacio, pero advertía, eso sí, lo que esperaba al respecto: «no dudando seria el correspondiente al que nos da en su Palacio con las mismas circunstancias, con las cuales all nos favorece en él, y sobre todo que en la pieza inmediata están los Señores Cardenales para tales funciones». La representación concluía con una suave protesta, ya que si el régimen de entradas a palacio se conculcaba, no podía esperarse que sólo los embajadores lo observaran: "y que relajandose con otros el rigor que se les manda observar, dejase menospreciables las honras que les están señaladas y que hasta ahora han gozado ... no dudando de la munificencia de su Real ánimo que, ponderados los reparos, se dignará mandar que se nos conserven sin alteración las preeminencias que han gozado nuestros antecesores".

Fuese un simple error o una provocación, el incidente con el Nuncio y el embajador de Saboya hacía salir a la luz oficialmente un problema que, soterrado, llevaba casi dos años gestándose en en entorno de Felipe V. En efecto, los accesos a las habitaciones regias en el Alcázar de Madrid y en el resto de los sitios reales venían observándose tradicionalmente en la corte del Rey

\footnotetext{
34 Nunciatura, [ ]-Vl-1703, A. G. P., Luis I, c.. 4.
} 
Católico de acuerdo a las viejas normas del ceremonial borgoñón, y su estilo -junto con el de las comidas públicas- había acabado por constituir uno de los elementos más identificativos del ceremonial español, al que se achacaba precisamente buena parte de la famosa invisibilidad del rey de España ${ }^{35}$. La cuestión es bien conocida, pero merece la pena recordarla para compararla con la que será la situación posterior. Desde época del Emperador Carlos V y aún de su padre-, el acceso a las habitaciones más privadas del monarca se había reglado -inspirándose en las primitivas disposiciones establecidas por Felipe el Bueno y Carlos el Temerario- de acuerdo a una sucesión jerárquica de salas, antecámaras y cámaras que precedían a las habitaciones más privadas, y cuyo acceso, cada vez más restringido, estaba firmemente regulado a tenor de la jerarquía de los personajes de la corte o de su disfrute de la gracia real. Claro que esta regulación había ido cambiando al compás del tiempo, de las costumbres reales y de las contínuas modificaciones de los aposentos de palacio, pero tanto las Etiquetas de la Casa y de la Cámara aprobadas por Felipe IV como los diferentes decretos sobre entradas habían fijado una situación bien conocida y ya familiar para los cortesanos de Carlos II y del primer Felipe $\mathrm{V}^{36}$.

\section{UN BREVE RECORRIDO POR EL ALCÁZAR DE CARLOS II}

El ingreso a las habitaciones del rey en la planta principal del Alcázar madrileño ${ }^{37}$ se realizaba a través de de una primera Sala - a donde desembocaba la escalera del patio del Rey-, conocida como la Sala de la Guardia por permanecer en ella los arqueros de la guardia real. Desde esta Sala se accedía a la liamada Saleta a la cual tenían acceso, además de algunos oficiales de palacio - Acroes, Costilleres, Barlet-Servant- «los Capitanes ordinarios, Procuradores de Cortes y algunos religiosos o personas eclesiásticas» ${ }^{38}$.

35 Sobre esta cuestión vease el ya clásico el estudio de PFandL, L., «Philip II und die Einführung...", pág, 14; que repite LISÓN TOLOSANA, C., La imagen del rey, págs. 141-143. Sobre su primitiva instauración, Dominguez CASAS, R., op. cit, págs. 547-624. Muy sugerentes son fas colaboraciones de BouzA, F., en la obra colectiva dirigida por MARTínez MiLLÁN, J.: La corte de Felipe II, pags. 37-72 y 451-599. Del carácter tradicional y ya arraigado que tiene medio siglo después el régimen de entradas según la disposición de las piezas del Alcázar dan buena cuenta las observaciones de GonzÁlez de Avlla, Gil, Teatro de las grandezas de la Villa de Madrid, Madrid, 1623, págs. 309-310.

36 «Razón de la observancia que habia en tiempo del Rey nuestro Señor (que haya gloria) en las entradas permitidas en su cuarto y Real Cámaram, A. G. P., Luis I, c. ${ }^{\text {a }}$; modificaciones durante la última enfermedad del monarca en Histórica, $c{ }^{a} 55$.

37 Sobre la vida en el Alcázar en época de los Austrias, IÑIGUEZ ALMECH, F., Casas reales y jardines de Felipe II, Madrid 1952; GeRARD, V., De Castillo a Palacio. El Alcázar de Madrid en el siglo XVI, Bilbao, 1984; Barbeito, J. M., El Alcázar de Madrid, Madid, 1992 y CHECA, F. (dir.), El Real Alcázar de Madrid. Dos siglos de arquitectura y coleccionismo en la Corte de los Reyes de España, Madrid, 1994.

38 A. G. P., Luis I, Caja 4.

Hispania, LVI/3, núm. 194 (1996) 965-1005 
La circulación por estas dos piezas estaba custodiada por los Porteros de Sala y Saleta, quienes debían vigilar que nadie excediese la entrada que le correspondía.

Seguía a continuación la Antecámara o Pieza del Dosel, así llamada por estar presidida por un trono adoselado. Utilizada en ciertos actos públicos, como las Consultas de justicia, las Proposiciones de Cortes del reino de Castilla o la Comida de Pobres del Jueves Santo, al pasar delante del trono era obligatorio para todo visitante descubrirse y hacer una reverencia. Tenían acceso a la Antecámara «los Gentileshombres de la Boca, Titulos, Caballerizos, Pajes, Tenientes de las Guardias, Alcaldes de la Casa y Conte, y el Ayo de los Pajes o su Teniente cuando vienen con ellos" ${ }^{39}$. El acceso a esta Antecámara y a la pieza siguiente estaba vigilado por los Ujieres de Cámara que custodiaban sus puertas.

A partir de aquí comenzaba propiamente la Cámara y Cuarto del Rey, que comprendía las diversas estancias privadas del monarca. Este área del palacio - que abarcaba el ala oeste y casi toda la sur del Alcázar- englobaba dentro de sí, no obstante, algunas piezas que en ocasiones se utilizaban para funciones públicas: el Salón Grande - usado para la representación de comedias, comidas públicas y todos aquellos actos que requirieran el concurso de la mayoría la corte-, y el Salón Nuevo o de los Espejos que, aunque en orígen había tenido carácter privado, fue usándose cada vez más para ceremonias públicas - como la recepcion de embajadores moscovitas ${ }^{40}$. Exceptuando las ocasiones en que estas habitaciones se abrían al público, el acceso a la Cámara y Cuarto del Rey era restringido y estaba estríctamente regulado por las disposiciones que sobre entradas se habían ido dictando a lo largo de los reinados.

La primera estancia, la Antecamarilla de Embajadores, ya hemos visto como servía para que los respresentantes diplomáticos de los estados católicos esperasen al monarca para acompañarle en las funciones públicas de Capilla. A ella volvían acabada la ceremonia, junto con los «títulos de toda España y de sus Reinos y Señorios, y también los del Imperion ${ }^{41}$.

La Pieza de la Cámara era utilizada para la primera recepción de emba jadores, y en ella esperaban también los cardenales cuando había función de Capilla. En sus audiencias privadas, los Cardenales eran recibidos - tras atravesar el cubillo y otra habitación de paso- en la siguiente pieza, que de ordinario se usaba como comedor privado del rey.

\footnotetext{
39 Ibidem.

40 Este carácter mixto de algunas piezas del Cuarto del rey daría, en ocasiones, lugar a que se suscitasen problemas de competencia y de jurisdicción entre eí Sumiller de Corps y el Mayordomo Mayor. Este último, en un memorial dirigido al rey, el 8 de mayo de 1742, trataba de dejar establecida la distinción: «Que aquélla (Cámara) no excede de lo que V.M. ocupa como vivienda ordina. ria... Que ésta (Casa) comprende todo lo que usa cuando comparece en funciones", A.G.P., Administrativa, leg. 368.

41 «Razón de las entradas en Palacio en las Audiencias y funciones de Ministros públicos de Príncipes extranjeros, observadas de cincuenta años a esta parten, A. G. P., Luis I, c.. 3; Felipe V, leg. 329; Histórica, c. ${ }^{\text {a }} 55$.
} 


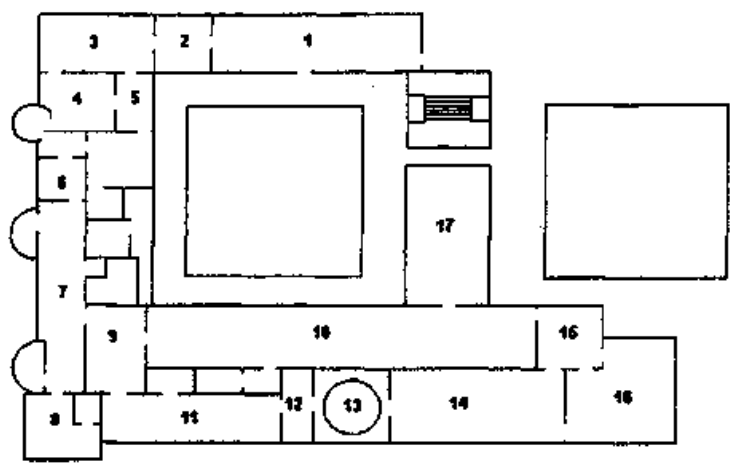

Figura 1: Distrîbución de la planta principal del Alcázar durante el reinado de Carlos II.

1 Sala de Guardias
2 Saleta
3 Antecámara o Pieza del Dosel
4 Pieza de la Cámara
5 Antecamarilla de Embajadores
6 Aposento donde come el rey
7 Galería Dorada
8 Torre del Despacho
9 Pieza Oscura

1 Sala de Guardias

2 Saleta

4 Pieza de la cámara

7 Galería Dorada

9 Pieza Oscura
10 Salón Grande de Cornedias

11 Galería del Rey o de los Grandes

12 Pieza del Pasillo

13 Pieza Ochavada

14 Salón Nuevo o de los Espejos

15 Pieza de las Furias

16 Dormitorio y vestidor de la Reina

17 Capilla

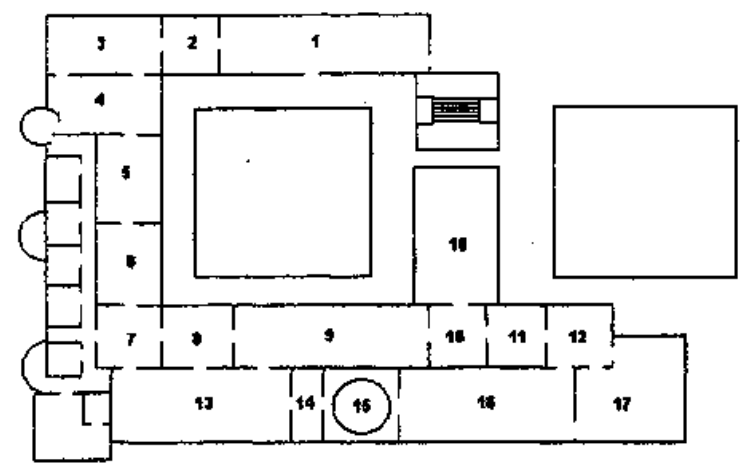

Figura 2: La nueva planta principal del Alcázar según los planos de Ardemans (1709) y Du Verger (1711).

1 Sala de Guardias

2 Saleta

3 Pieza de Consultas

4 Pieza de Audiencias

5 Primera Antecámara

6 Segunda Antecámara

7 Pieza Oscura

8 Antecámara del Rey o Vestuario de las Comedias

9 Gran Salón para Sus Majestades en particular
10 Pieza del Cancel

11 Dormitorio de Sus Majestades

12 Pieza de las Furias

13 Salón Nuevo de Grandes

14 Pieza del Pasillo

15 Pieza Ochavada

16 Salón de los Espejos

17 Tocador de la Reina

18 Capilla

Hispania, LVU/3, núm. 194 (1996) 965-1005 
Olvidando la serie de aposentos y alcobas de servicio de la crujía interior -aparador, guardarropa, retrete, etc,--, se extendía hasta la Torre Dorada -o del Despacho - la Galería Dorada - o Pintada - con sus ventanales sobre el Manzanares, a la que tenían acceso en época de Carlos II los títulos y "personas conocidas".

Desde ésta, y antes de llegar al despacho del rey, se accedía a la Pieza Oscura, donde tenían entrada "los Gentileshombres de Cámara sin ejercicio ni entrada, los Primogénitos de Grandes, Consejeros de Guerra, Capitanes Generales de mar y tierra, Ministros de Campo generales de los Ejércitos de España, Flandes e Italia y Almirantes Generales de la Armada del Oceáno». También eran recibidos alli por el rey los Presidentes de los Consejos.

Los Grandes de España tenían acceso hasta la pieza siguiente, también contigua al despacho, llamada Galería del Rey - y luego de los Grandes, quienes "en entrando el mantel para la comida de S.M." podían tener entrada hasta la Pieza de los Espejos o allí donde comiera el monarca, no siendo en el cuarto de la reina. A esta Galería de Grandes accedían asimismo los consejeros de Estado y, para sus audiencias privadas le estaba también permitida la entrada al embajador de Alemania, considerado como "doméstico" del rey - privilegio extendido al embajador francés desde el matrimonio de Carlos II con María Luisa de Orleáns-.

Los Mayordomos de Semana del rey y la reina tenían su entrada hasta «la pieza que llaman el pasillo, inmediata a la de los Grandes», para aguardar las órdenes de su majestad.

$\mathrm{El}$ acceso al dormitorio del rey -frecuentemente la Sala de las Furias, contiguo al cuarto de la reina- estaba estríctamente reservado para los tres jefes de palacio: el Mayordomo Mayor, el Caballerizo Mayor - a las horas convenidas-y el Sumiller de Corps - a cualquier hora-. Igualmente, gozaban de entrada libre los Gentileshombres de Cámara con ejercicio, los de entrada -no estando el rey acostado o vistiéndose o desnudándose-y los Ayudas de Cámara. Para soslayar problemas en el servicio diario del rey se entregaban llaves de Ayuda de Cámara también al Aposentador de Palacio, a los jefes de la Tapicería y del Guardarropa y al Secretario de la Cámara. El resto del personal tenía acceso al dormitorio real sólo cuando sus servicios eran requeridos por el Sumiller o los Gentileshombres y estaba minuciosamente regulado por las etiquetas de la Cámara.

\section{El CONSEJo DE ESTAdo SE PRONUNCIA}

¿Qué quedaba de este riguroso ceremonial hacia 1703 ? No es fácil saberlo, pero todos los testimonios apuntan en una misma dirección: no se observaba estríctamente. Se lo saltaban, desde luego, los criados de la familia francesa, muchos de los cuales aún sirviendo fuera de la planta ordinaria de la Cámara, mantenian una familiaridad inusitada con el rey. Aparte, había que considerar el enjambre de ministros y militares que, bajo los auspicios de Versalles, trataban de dirigir los rumbos de la Monarquía en los primeros años de la

Hispanid, LVU/3, nủm. 194 (1996) 965-1005 
sucesión. Todo ello contribuía a crear en el Alcázar una atmósfera enrarecida de problemas y cuestiones protocolarias en donde estaban en juego, tanto el prestigio y la jerarquía de los individuos implicados como, y por encima de todo, el acceso a la persona del rey, componente clave de la economía de poder de la corte ${ }^{42}$.

La representación del Nuncio antes analizada fue enviada al Consejo de Estado para su estudio. Los consejeros, sin conceder demasiada importancia al incidente diplomático, aprovecharon sin embargo la consulta para poner de manifiesto ante el rey la importancia que tenía para la corte el respeto al viejo ceremonial palatino de los Austrias y la necesidad de regular el acceso a la persona real "pues, aunque parece cosa material, es de grave importancia y conveniencia stu observancia», corrigiendo "los abusos actuales en materia de entradas (...) de que nos consta a todos los que asistimos a esta tabla». El voto pronunciado por el Conde de Frigiliana puede servir perfectamente como ejemplo de la opinión y del malestar imperante entre los cortesanos, que veían en la decadencia del antiguo ceremonial de entadas el derrumbe de sus propios privilegios o la revocación de inmemoriales gracias y mercedes reales:

«entrando el nuncio en una cosa para (la) que no tiene derecho, como la de pretender que V.M. regle su Palacio, le hace el mayor servicio con la ocasión que nos da para decir a V.M. que, observando sus antiguados estilos, estudiados por sus gloriosos Progenitores y convenidos con el genio de sus vasallos (que son las reglas con que aquellos se forman), logrará V.M. dos altos fines muy geniales a la Nación. El primero, aquel gran decoro con que vivía la Majestad entre su primera y elegida nobleza, dejando a los que no la lograban dependientes de un ardentisimo deseo de merecer respectivamente, según sus calidades y méritos, poder entrar una Pieza más en Palacio, hasta llegar a los reales pies de V.M., labrando en este estimable honor los señores Reyes un herario con que, sin dispendio de los caudales, premiaban las fatigas con que se deseaban merecer los grandes servicios (...) Cuando esto se trataba asi, tenia V.M. en estos premios la corona de laurel de los romanos, y cuando estos honores se hacen comunes, defraudada su estimación, no equivale su premio a lo que valia, ni anhelará su primera nobleza a ellos como lo hacia. Bien ha sido notado este serio proceder fuera de estos Reinos, pero a este compás era conocido de sus reyes cuán necesaria era su observancia, por no consentir lo igual el genio distinto de las Naciones, haciéndose forzoso conve nirlos con la que se domina o se manda. Bien sabe, que se supone que el retiro del rey no concilia el amor de sus vasallos. Esto se dice, señor, pero lo que es cierto es que, sobre que establece el respeto, no habrá quien se lo niegue, que ningtin soberano fuera tan amado de sus súbditos como los predecesores de VM. y nuestro amosn 43 .

También el Marqués de Mancera concluía su intervención reconociendo la necesidad de "dar forma permanente a esta materia", pero advirtiendo al

42 Hespanha, A. M., La gracia del derecho. Economia de la cultura en la Edad Moderna, Madrid, 1993, pags. 177-202.

43. Consulta del Consejo de Estado de 17 de julio de 1703, A. G. P., Luis 1, c. ${ }^{2} 4$.

Hispania, LVI/3, núm. 194 (1996) 965-1005 
monarca de los posibles agravios que se podían levantar, tal y como venía sucediendo: "no se puede empezar la reforma de esta relajación por partes; es menester idearla en el todo, executarla en el todo, y observarla precisamente en el todon.

Leída la consulta, el monarca decidió devolverla al Consejo, pidiéndole nuevamente su parecer sobre alo que convendría executar». Pero esta segunda consulta ${ }^{4}$ planteaba por lo pronto un grave problema a los consejeros, ya que la cuestión del ceremonial y de las etiquetas palatinas no era materia que competiese tanto al Consejo de Estado como a los Jefes de Palacio y al Bureo. Todos los asistentes, votaron entonces a favor de que se pidiera información y opinión a los oficiales de las casas reales pues, como señalaba el conde de Frigiliana, respecto a los eformularios (de las etiquetas) hechos por tan Grandes Reyes, no se resolverá el respecto del que vota a decir sobre ellos otra cosa que el venerarlos; su ejecución corresponde a los Jefes". Y advirtieron, una vez más, de los riesgos que se corrían al abrir un proceso de revisión del reglamento de entradas: «si V.M. no lo hace observar inviolablemente, tenga V.M. a bien que le diga que servirá sólo para hacer más odioso el abuso, y que la malignidad diga que se quiere saber para reirse de ello".

La materia, sin embargo, era lo suficientemente grave como para que, consultados por segunda vez, los consejeros no aprovecharan la ocasión de volver a manifestar su disgusto por la situación imperante, apuntando ya a algunos de los culpables. El duque de Medinaceli recordaba cómo, siendo su padre Primer Ministro, Carlos II le había concedido la llave de Gentilhombre de Cámara, permitiéndole así entrar «a las piezas donde ahora ve (a) tantos, que sólo el deseo de lograr la gran satisfacción y honra de ponerse a los reales pies de V.M. aparta el reparo que aquel concurso ocasiona». Y el Conde de Fuensalida iba más allá, reprochando directamente al monarca incumplir sus juramentos y compromisos con el Reino, al violar y abolir los privilegios palatinos de su nobleza:

"a su decoro, a su respeto, a su servicio conviene el que V.M. mande observar rigurosamente las referidas etiquetas (...) que nunca será V.M. más amado y respetado de estos buenos vasallos que cuando V.M. siguiere los dictámenes y reglas que pusieron en su real Palacio los Señores Reyes Felipe $2 .^{\circ}, 3 .^{\circ}$ y $4 .^{\circ}$, que fueron venerados de todos estos Reinos y muy especialmente de la nobleza en este punto.

Señor, la Nación Española no admite familiaridades con su Rey, y mucho menos el verse preferidos con desigualdad. Las entradas en el cuarto de V.M. están relajadas con escándalo, pudiendo decir el que vota que, hallándose un día de esta semana en la Galería de los Grandes (que es a donde es su entrada), vio entrar, a titulo de acompañar al Conde de Ursel, a un Capitân de Infantería Española reformado que le dijo iba con el Conde a la mesma Cámara de V.M. para tomar Audiencia, lo que no se atrevió a hacer el Conde, conteniéndose en los limites de su entrada, siendo asi que el Conde iba para hablar y ponerse a los pies de V.M.

Esto, Señor, que parece materia gubernativa y que repugna a la libertad común de las gentes, que prescriben los particulares cada uno en su casa que con más razón

44 Consulta del Consejo de Estado de 28 de julio de 1703, A. G. P., Luis I, c.. 4. 
la debería tener V.M., es materia de gravisimo escripulo en el fuero de la conciencia. V.M. tiene jurados a estos Reinos las leyes, fueros, estilos y costumbres, y confirmados todos los honores y dignidades, con que no es de dudar vienen a quedar revocadas las prerrogativas de las dignidades con esta relaxación del Palacio de V.M."

¿Quiénes eran los responsables de esta situación? El nombre de la Princesa de los Ursinos fue el primero en aparecer, aunque el marqués del Fresno la disculpara calificándola como "una mujer de tan gran dignidad que sólo puede faltar por no saber nuestros estilos". Estaba claro, también, que quienes más libertades se tomaban eran los criados franceses del séquito del monarca que "en virtud de la tolerancia, se hallan en posesión de entrar libremente». Los consejeros recomendaron al respecto que, habiendo "algunos que sean más del real cariño de V.M.», se les debía integrar en la planta ordinaria de la Casa del Rey, concediéndoles llave de Gentilhombre de Cámara -como había sucedido con el Marqués de Louville-o bien de Ayuda de Cámara. Y, en cualquier caso, consultar con el Rey Cristianísimo «para que asi, mediando su real prudencia, se de el ultimo retoque a lo que inviolablemente se hubiere de observar". No faltaría quien, sin embargo, echase en falta la autoridad del propio rey: "que la etiqueta que más falta hoy en Palacio es que V.M. mande lo que quiere que se execute y lo repare y riña mucho cuando no se hiciere».

\section{EL REY NO MANDA EN PALACIO}

No erraba el tiro el conde de Santiesteban al hacer este último reproche. De hecho, quien menos parece haber participado en la regulación de la vida palatina durante los primeros años de su reinado es el propio Felipe V. A su llegada a Madrid había manifestado su expreso deseo de hacerse servir únicamente por la real familia que traía en su viaje ${ }^{45}$, y durante las semanas siguientes se mostró siempre incómodo a la hora de tratar incluso con los jefes su casa. Según contaba Saint-Simon, "como incluso éstos eran extraños para él, y asimismo el duque D'Harcourt, gustaba de sustraerse al trato de todos ellos para estar solo son los pocos franceses que le habian acompañado, entre los cuales estaba especialmente habituado a Valouse, caballerizo suyo en Francia, y a Louville, que desde la edad de siete años era gentilhombre a su servicio" ${ }^{46}$. De poco servian los designios de Versalles para hacer visible al Rey Católico, si éste intentaba constantemente ocultarse en sus habitaciones cuanto le era posible, hasta el extremo de desatender los negocios de Estado. La famosa gravedad de Felipe de Anjou, tan celebrada en Versalles por considerar que le daba "todo el aire de un Rey de España", no era sino la máscara tras la cual el príncipe ocultaba su retraimiento, su apatía y la falta de confianza en sí mismo ${ }^{47}$. Los testimonios de esta época no dejan lugar a dudas: Felipe V, capaz de suscitar el entusiasmo popular por su aspecto físico - tan diferente del de Carlos II-, y por su valor en las acciones militares, se había inhibido

\footnotetext{
45 A. G. P., Felipe V, leg. 311.

46. Saint-Simon, Duque de, Memoires, I, pág. 878.

47 BOTTINEAU, Y., op. cit., pág. 112.
} 
muy rápidamente de buena parte de sus deberes como soberano y, en particular, de las obligaciones ceremoniales ${ }^{48}$.

Ello explica, precisamente, el giro de Luis XIV en su primera decisión de respetar cuanto se pudiera la organización de la corte madrileña y de sus instituciones de gobierno. Las instrucciones para el nuevo embajador, Marcin, son taxativas a este respecto y en ellas parece latir, como indicara Baudrillart, el convencimiento de que "sólo la reforma de la corte haría posibles todas las demás» ${ }^{49}$. Según su abuelo, el rey de España debía aplicarse con mayor diligencia a atender sus obligaciones y llenar de actividad todas sus horas, desechando «el fastidio que empieza ya a atomentarle». Pero todavía parece achacarse desde Versalles a la etiqueta española el desajuste de la situación:

"en todos tiempos, y los españoles convienen en ello, la etiqueta ha puesto una barrera entre el principe y sus súbditos, y desea S.M. que su nieto desate estas ligaduras, ya que hasta el día el interés de sus principales servidores y el de los grandes se lo haya impedido. No es una razón el ejemplo del rey difunto para conservar esta etiqueta, porque a este aislamiento se achacan las desgracias de España, y alabará el pueblo una conducta opuesta. Más querrá éste que el rey, su señor, siga el ejemplo del rey de Francia que el de sus antecesores autriacos; y si de éstos fuera indispensable escoger alguno por modelo, seria mejor que siguiese el ejenplo de Carlos I en una parte de su conducta, que el de los sucesores de ésten.

Por un principio de prudencia política insoslayable, y previendo las próximas jornadas del monarca, las instrucciones añadían que «el rey de España podrá mejor fuera de Madrid que en la capital ... abolir la etiqueta» ${ }^{50}$.

La jornada de Cataluña, pero, sobre todo la de Italia de 1702, brindaron una espléndida oportunidad para que el séquito francés de Felipe V intentará transformar el ceremonial español. En Nápoles, cuenta Marcin, se había instituido con gran éxito una ceremonia para el monarca que reproducía casi integramente el lever de Luis XIV ${ }^{51}$. Con todo, Felipe V no colaboraba demasiado y, en Milán, en medio de los agasajos generales, tuvo una de sus primeras crisis agudas, negándose a hablar con nadie y no queriendo ver «sino a aquellos a quienes estaba habituado" ${ }^{52}$. Además, una cosa era fascinar a la

48 CoXe, W., op, cit., I, pág. 109.

49 Baudrillart, A., Philippe Vet la Cour de France (5 vols. París, 1890-1901), 1, pág. 79.

so Sobre estas instrucciones vid. Coxe, W., op. cit., I, págs. 113-118. Ya en diciembre de 1701, durante la jornada de Cataluria, la Princesa de los Ursinos revelaba en una carta a Torcy el clarisimo rechazo del séquito francés de los monarcas respecto al uso de la "cortina» que, según las etiqueta española, debía ocultar en las iglesias al monarca de la vista del resto de los asistentes: "Además asistieron SS.MM. a la iglesia por la mañana y por la tarde, sin cortinas, porque no las habia, lo cual hacia decir a los españoles que no podia verificarse la ceremonia. Nosotros empero, nos alegramos mucho de esa infracción de la etiquela, y si hubiera habido cortinas, no nos hubiéramos servido de ellas, pues el capricho de ocultar al pueblo un rey anable, era who de los menos juiciosos de Felipe II", Ibidem, pág. 135.

51 BotTneau, Y., op. cit., pág. 208.

52 BaudrililarT, A., op. cit., l, págs. 109-110. 
nobleza provincial, acostumbrada a las aburridas cortes virreinales, y otra bien distinta revolucionar el alcázar de Madrid con los usos de Versalles, allí donde las costumbres tradicionales estaban más arraigadas y las resistencias a vencer eran mucho mayores.

En realidad, durante los años siguientes, pocos fueron los hábitos de la corte que el propio Felipe V mostrara un interés personal por transformar, más allá de instalar en palacio un dormitorio común con la reina y de hacerse servir personalmente por sus criados franceses ${ }^{53}$. La instrucciones del Cardenal de Estrées vuelven a manifestar la preocupación de Versalles por este extremo: "desvía el rey a los españoles de su servicio a causa de una preferencia sobrado manifiesta hacia los franceses ${ }^{54}$. En 1705, los informes del Mariscal de Tessé confirman la poca atención que el soberano concedía a su entorno doméstico ${ }^{55}$, añadiendo que poco podían hacer la reina o la princesa de los Ursinos para reformar la etiqueta epañola "si por su parte el rey no fuera todavía menos expansivo que los españoles; porque exceptuando la caza que gusta mucho a S.M., y aún entonces es preciso que esté casi solo, su temperamento le inspira deseos de no ver a nadie; y si no estuviera ya tan arraigada la etiqueta en España, bastaría él para establecerla" "56. Buena parte de la reorganización de la Casa del Rey apunta en esta misma dirección: Felipe $\mathrm{V}$ trató de potenciar aquellos componentes del viejo ceremonial hispano-borgoñón que contribuían a acentúar su aislamiento, al tiempo que organizaba su servicio más personal de acuerdo a un estilo que recuerda más a la casa del duque D’Anjou que a la del Rey Católico.

Está claro que Felipe V difícilmente reunfa las cualidades personales necesarias para desempeñar el papel de gran maestro de ceremonias de la corte de Madrid, tal y como había hecho su abuelo en Versalles. ¿No había sido, en realidad, la gran capacidad de control y de innovación que tuviera Luis XIV en su corte lo que más pudiera contrastar con el entorno de Carlos II, rodeado de grave y grandiosa majestad, pero prisionero de unas etiquetas meticulosamente codificadas por su padre y sostenidas a rajatabla por la alta nobleza palatina a causa de las prerrogativas que cerca de la persona real le concedían?

Indiferente hacia buena parte de los detalles de su servicio, Felipe V dejaría actuar a sus más allegados: Louville, primero, la Princesa de los Ursinos apoyada por la reina, después, Orry para las materias hacendísticas y, desde luego, los sucesivos embajadores de su abuelo. Yves Bottineau ha acertado plenamente al describir a la Princesa de los Ursinos como la cabeza rectora del palacio desde la partida del marqués de Louville y hasta su propia expul-

\$3 Este dormitorio real aparece ya en el plano de Ardemans de 1705, vid. Barbeito, op. cit., pág. 202.

s4 CoXE, W., op. cit., I, pág. 183.

55 «El rey se cuida tanto de tener casa o no tenerla, guardias a caballo, guardias a pie, muebles, carrujaes de terciopelo o lienzo, lo mismo que me importa a mí tener un lacayo más o menos", citado por COXE, W., op. cit., I, pág. 256.

56 Ibidem, pág. 251.

Hixpania, LVI/3, núm. 194 (1996) 965-1005 
sión en $1714^{57}$. Nadie como ella disfrutó de la confianza de Luis XIV durante la mayoría de su estancia en Madrid, y nadie conocía tampoco tan bien como ella los usos y costumbres de la corte francesa ${ }^{58}$.

A la de los Ursinos se deben las sucesivas innovaciones llevadas a cabo en la vida cotidiana del Alcázar y del Buen Retiro, aún manteniendo en gran parte el ceremonial español y las etiquetas de tiempo de Felipe IV. A fuerza de alagar cuando era preciso a los grandes y de proporcionarles empleos ${ }^{59}$, de contemporizar con los altos oficiales de palacio ${ }^{60}$, y de saber encajar de cuando en cuando sus afrentas ${ }^{61}$, la princesa consiguió establecer una situación de hecho bastante satisfactoria para sus soberanos, aliviando la presión en parte del viejo ceremonial e introduciendo algunas manifestaciones de la vida cortesana francesa.

Para llevar a cabo su cometido, además de la confianza de los soberanos, la princesa pudo contar con un instrumento precioso que pusiera en sus manos la costumbre de Felipe $\mathrm{V}$ de compartir el dormitorio con su esposa: la facultad, como Camarera Mayor de la reina, de repartir el ceremonial de la alcoba real con el Sumiller de Corps ${ }^{62}, \mathrm{y}$, por supuesto, el libre acceso al cuarto del rey ${ }^{63}$.

Y precisamente el acceso al cuarto del rey y su regulación iba a constituir uno de los puntos fundamentales a reformar de las viejas etiquetas.

57 BotTineau, Y., op. cit., págs. 207-210.

58 En espera de una nueva biografia sobre este personaje, vid. CEMARKIAN, M., La Printcesse des Ursins. Sa vie et ses lettres, Paris, 1969; sobre su labor como Camarera Mayor, págs. 259-338.

59 "Todos los grandes de primera clase intrigan y en lo último que piensan es en el bien del Estado. Es necesario ganarlos con buenas palabras e, incluso, por medio de empleos en que no puedan perjudicar si tienen malas intenciones», cit. por BOTTINEAU, Y., op. cit., pág. 185.

to lbidem, pág. 208.

6l El marqués de San Felipe recoge en sus Comentarios el descotento con que fue acogido el nombramiento de la Princesa de los Ursinos como Camarera Mayor de la reina: upara este empleo en que era preciso criar a una tierna princesa con la etiqueta y seriedad española», pág. 31. Sobre sus primeros encontronazos con algunos altos oficiales españoles, CoXE, W., op. cit., I, págs. 132-134.

62 No tiene desperdicio sus regocijantes cartas a la duquesa de Noailles y a Torcy en sus primeros tiempos junto a los reyes: «... soy yo quien tiene el honor de tomar la bata del rey de España cuando se acuesta y de darsela con sus babuchas cuando se levanta. Esto lo llevaria con paciencia, pero todas las noches, al entrar el rey en la cámara de la reina, me entrega el conde de Benavente la espada de S.M., una bacinilla y una lámpara que suele manchar mis vesidos; esto es grotesco en demasía. El rey no se levantaría en todo el día, si no descorriese yo la cortina de su cama, y sería un sacrilegio que entrase otra persona que no fuese yo en la cámara real cuando SS.MM. están acostados. Una de estas últimas noches se apagó la lamparilla, porque había derranado yo la mitad del aceite (...), poco me faltó para que me rompiese las narices contra la pared, y anduvinos durante un cuarto de hora el rey de España y yo dándonos tropezones, buscando el medio de hallar luz», CoXe, W., op. cit., l, págs. 431-432.

${ }_{63}$ Su capacidad para filtrar las entradas en el cuarto del rey fue precisamente una de las armas que la Princesa pudo utilizar para neutralizar al Cardenal de Estrées y a su sobrino en el tiempo que duró su embajada, vid. BotTineaU, Y., op. cil., pág. 209. 


\section{7. economía y policfia de la REAL casa}

La consulta del Consejo de Estado de 28 de julio de 1703, que hemos visto anteriormente, dio como primer resultado el que en palacio se realizara una encuesta entre los jefes, pidiéndoseles la documentación conservada en sus respectivas oficinas sobre los reglamentos de entradas ${ }^{64}$.

No fue hasta un año después, el 11 de agosto de 1704, que Felipe V se deciera a dictar un decreto disponiendo que las entradas en palacio se observasen «exactamente según se hacía antiguamente» ${ }^{65}$. Pero la medida a aquellas alturas era casi imposible de aplicar de forma rigurosa, y el día 15 se daba ya una primera orden particular para que no pusiera "embarazo en su entrada" al marqués de Valouse, por entonces Mayordomo de semana del rey ${ }^{66}$.

Y no sólo eran los particulares acostumbrados a tener entrada libre al cuarto del rey los que iban a plantear problemas ${ }^{67}$. La reforma de las guardias de corps, dirigida por el embajador Amelot y la Princesa de los Ursinos, y puesta en marcha por las mismas fechas, exigió una ampliación inmediata de las entradas para los oficiales de las compañías recién creadas ${ }^{68}$. Dictadas el 12 de junio de 1704 en plena campaña de Extremadura, las Ordenanzas de estas cuatro nuevas compañías de Reales Guardias de Corps estaban condenadas, sin embargo, a crear otros infinitos problemas en la corte. Inspiradas en el modelo de Versalles, dichas ordenanzas disponían una particular y estrecha relación entre el monarca y el Capitán de la guardia de servicio que, irremediablemente, introducirfa importantes modificaciones en la vida cotidiana de palacio y en sus etiquetas 69 .

Para empezar, el capítulo $1 .^{\circ}$ de las ordenanzas decretaba que los capitanes de las guardias debían recibir todas las órdenes, de voz o por escrito, directamente del monarca, lo que constituía una grave merma para la autoridad del Mayordomo Mayor que siempre había tenido bajo sus ordenes directas a los capitanes de las viejas guardias de corps, sirviendo de intemediario entre éstos y el monarca. Ante las protestas del marqués de Villafranca, y en atención a su persona, se suspendió la aplicación de este capítulo para la antigua Guardia de Alabarderos en tanto el Marqués continuara siendo Mayordomo Mayor del rey.

Pero también los capítulos $2 .^{\circ}$ y $3 .^{\circ}$ de las mismas ordenanzas iban a provocar problemas. En ellos el rey disponía que, desde el momento en que abandonase su Cámara, el Capitán que estuviera de servicio "me ha de seguir en todas partes inmediatamente a mi persona (...), de forma que entre el Capitán y

${ }^{6}$ A. G. P., Histórica, c. ${ }^{\text {a. }} .55$.

65 Ibidem.

tó A. G. P., Histórica, c.". 184.

67 Al Decreto de 11 de agosto de 1704 le seguirian, a lo largo del año, una innumerable lista de órdenes particulares concediendo entradas a la Cámara del rey, A. G. P., Felipe V, leg. 312.

68 A. G. P., Histórica, c.". 55; Administrativa, leg. 623.

69 A. G. P., Histórica, c.”. 184.

Hispusia, LVI/3, nư่m. 194 (1996) 965-1005 
mi Real persona, no pueda haber otro alguno". Y lo que era peor: "en cualquier función pública, sin excepción de paraje alguno, estará el capitán detrás de mi silla». Toda una revolución en los usos tradicionales de palacio y en el ceremonial que solía reservar para los jefes de palacio, no estando presente otra autoridad superior del reino, el lugar inmediato a las personas reales.

La oposición más tajante, sin embargo, no provino de los jefes de palacio, bastante molestos con el reglamento, sino de los grandes, inquietos ante la marcha de los acontecimientos políticos y celosos de que sus prerrogativas y su papel en la corte continuara siendo atacado por la camarilla francesa del monarca. La ocasión la brindó un Te Deum que debía cantarse en la capilla de palacio el 25 de agosto de 1705 para celebrar la onomástica del rey de Francia y los éxitos militares del duque de Vendôme. El incidente, conocido como el «caso del Banquillo", haría correr ríos de tinta y provocaría un importante escándalo en la corte ${ }^{\text {to }}$.

Todo el problema radicaba, de nuevo, en la proximidad a la persona real. Tradicionalmente, los grandes habían ocupado en la capilla del Alcázar un banco reservado a continuación del sitial del soberano, de forma que entre éste y la grandeza únicamente se interponía la silla de tijera dispuesta para el Mayordomo Mayor. Para evitar los habituales lances por cuestiones de protocolo y precedencia en un lugar sagrado como aquél, se habja dispuesto incluso que en tal banco los grandes debían ir ocupando sus asientos según fueran llegando, pero nunca por orden de jerarquía ${ }^{71}$. Con la presencia ahora del Capitán de las guardias la situación cambiaba. El Capitán de la compañía de corps flamenca, el príncipe de Tserclaes, acababa de recibir la grandeza y Felipe $V$ decidió que para aquella ceremonía debía ocupar un banquillo semejante al del Mayordomo justo detrás de su persona.

Los grandes, juzgando la innovación intolerable, decidieron oponerse corporativamente a ella. Según su argumento, la decisión real no sólo implicaba elevar al Capitán de las guardias por encima suyo, sino interponer además a alguien entre ellos y el soberano, por lo que defendían, como única solución posible, que el príncipe de Tserclaes ocupara el mismo banco que el resto de los grandes, abandonando su lugar detrás del rey y contraviniendo las ordenazas de las nuevas guardias. Airados hasta el extremo, la mayoría decidieron no asistir a la función a la que el monarca les había convocado. Los duques de Medinaceli y de Montalto llegaron a asegurar al presidente del Consejo de Castilla "que podía preparar castillos donde enviarles, y que ellos irían más gustosos que a la capilla». El duque de Sesa y el conde de Lemos, ambos capitanes de las guardias españolas, se permitieron declarar «que primero eran duque de Sesa y conde de Lemos, que capitanes de la guardia, porque lo uno lo habia hecho Dios, y lo habian de ser sus hijos y descendientes, y lo otro era temporario y dudoso" ${ }^{72}$. Junto a los grandes, la mayoría de los altos oficiales de

70 Entre otras muchas relaciones manuscritas del suceso pueden consultarse, B. N. M., mss. $2.776 ; 10.681 ; 11.007 ; 11.424 ; 11.641$.

71 A. G. P., Histórica, C. 54.

72 Baudrillart, A., op, cit., t. I, págs. 234-236; Bottineau, Y., op. cit., págs. 204-206. 
palacio se solidarizaron con sus iguales, boicoteando la asistencia al acto. Para dar menos relevancia al escándalo, Felipe $V$ se resignó a asistir en privado al cancel de la capilla como si no hubiera habido función pública ${ }^{73}$.

Por segunda vez, los grandes se oponfan a una reforma del protocolo iniciada por el soberano y por idéntico motivo: la posible intromisión de alguna figura que pudiera distanciarles de la persona del rey ${ }^{74}$. Y aquello era precisamente lo que representaba el banquillo del capitán de las guardias: una barrera simbólica erigida entre el cuerpo de la grandeza y el cuerpo del rey. Estaba claro que, más allá de la anécdota, el incidente del banquillo representaba sólo un episodio más de la enconada lucha que la nobleza cortesana española estaba decidida a oponer a las reformas de Felipe $V$ y de sus consejeros, dispuesta a no ceder sin resistencia un sólo ápice de sus privilegios cerca de la persona del rey ${ }^{75}$.

Levantada la polvareda, los oficiales de palacio consideraron también llegado su turno. Habiendo muerto el marqués de Villafranca a comienzos de junio de 1705, y aprovechando el nombramiento -dilatado durante mesesdel nuevo Mayordomo Mayor -el Condestable de Castilla-, Felipe V decretó el 18 de septiembre de 1705 la plena puesta en ejecución de las ordenanzas de guardias elaboradas el año anterior, acompañadas de unas instrucciones particulares sobre "el modo de servir sus Reales Guardias de Corps y la de Alabarderos en la Corte y fuera de ella, y en todas las funciones publicas y particulares" ${ }^{76}$.

Pese a que estas instrucciones reconocían claramente y respetaban la preeminencia dentro de la Cámara del Sumiller de Corps y de los Gentileshornbres de la Cámara por encima del Capitán de las guardias, el conde de Benavente se lamentó al rey en nombre de éstos, transmitiéndole «su grande mortificación de que en su tiempo haya de decaer la autoridad y preeminincias de los Gentileshombres de Cámara, cuyo empleo ha sido tan atendido como

73 Sobre este incidente el marqués de San Felipe dejaría constancia en sus Comentarios concluyendo que «Algunos (grandes) cederían luego al gusto del Rey; otros, con el tiempo, y otros, nunca", págs. 101-102.

74 La primera vez que los grandes protestaron colectivamente, por boca de los duques de Arcos y Baños, fue en julio de 1701, oponiéndose a la reciprocidad de tratamiento, acordada entre las cortes de Madrid y Versalles, para los los duques y pares de Francia y los grandes de España (A. G. P., Registros, núm. 547, f. 169v-170r.). Para estos últimos, el problema residia en que en España, entre el rey y ellos, sólo se interponían en rango el príncipe de Asturias y los infantes, mientras que en Francia, entre el soberano y los duques y pares habia otros cuatro cuerpos: los hijos y nietos de Francia, los principes de la sangre, los principes hijos naturales de rey, y los príncipes extranjeros. Más que dirimir una cuestión de calidad entre ambas noblezas, se trataba de defender la proximidad de la grandeza al soberano. El Memorial del duque de Arcos, entre muchas otras copias, en B.N., mss. 10,681 y 17.514; y publicado en el Semanario Erudito de Valladares, t. 24, págs. 131 y ss. Ver asimismo BotTineAU, Y., op, cit., págs. 183-184.

${ }^{75}$ Preocupado por el escándalo Luis XIV escribiria a su nieto que $«$ Es desagradable dar lugar a que se crea públicamente que hay una declarada división entre V.M. y los grandes de vuestro reino y que éstos forman juntos un cuerpo rebelde a vuestras órdenes, Sin embargo, vos no podéis renunciar a lo que habéis hecho*, en BAUDRiLlarT, A., op. cit., t. I, pág. 235.

${ }^{76}$ A. G. P., Administrativa, leg. 623.

Hispanita, LVU3, nún. 194 (1996) 965-1005 
favorecido de los gloriosos progenitores de V.M. para conservarlos siempre con indemnidad" 77 .

Mucha mayor enjundia revistió la consulta impresa elevada ante el rey por el Bureo, que, a todas luces, seguía viendo una grave amenaza para la autoridad de los Mayordomos en la figura del Capitán de las guardias quien, ahora, les precedía delante del rey, les hurtaba la custodia de la persona real y de las llaves de palacio, y les privaba a diario de recibir de boca del monarca las órdenes que antaño a ellos les correspondía recibir y ejecutar ${ }^{78}$.

Presentándose a sí mismo "como consejo que V. Mag. tiene formado para todas las materias Aúlicas, a quien (como a todos los demás desta Corona) manda V. Mag. le representen quanto se ofrezca", y al Mayordomo Mayor como "Virrey y Presidente del Real Palacion, el Bureo emprendió una feroz defensa de las prerrogativas de los oficiales del palacio y de la organización tradicional de éste, decidido a dar al rey toda una lección sobre los principios políticos del gobierno de la corte española. Para sus miembros resultaba inadmisible la autoridad que en adelante se entregaba en palacio a un cargo militar como era el del Capitán de las guardias de corps:

"Las Cortes, Señor, son las Universidades del Goviemo Politico, de las artes de la paz, de la distinción de los vassallos; en ellas se arma la Magestad del braço de sus leyes; los triunfos Militares estan en ellas para el aplauso, no para el estruendo. (...) Assi en los Palacios, que son el solio del Goviemo Politico, donde vive el mejor concierto de las Gerarquias de los vassallos, y donde vienen los mas esforçados Capitanes a recibir el premio de sus servicios en los quietos honores y empleos de la paz, deben ceder todas las Escuelas a la Politica, en cuya disciplina viuen quantos sirven dentro de la Real Casa, y estar a las ordenes de los empleos que tiene la Corona erigidos para la mejor planta y arreglamento de su decoro» ${ }^{79}$.

Para avalar sus argumentos, el Bureo apelaba al ejemplo de Luis XIV y Versalles, aludiendo al abandono de la capital por el soberano con cierta malevolencia:

"siempre ha seguido este Principe la gloria Militar; siempre ha estado su marcial espiritu hospedado mas agradablemente con la solemnidad de campaña en los Palacios de Bersalles y otros que ha edificado magnificamente para este fin; pero no por esso ha suprimido los arreglamentos del Palacio de Paris, que es el de planta de la Corona, en que tiene el Mayordomo Mayor tan altas preeminencias».

77 A. G. P., Histórica, c. ${ }^{a} 184$.

78 Consulta del Bureo de 12 de noviembre de 1705, A. G. P., Histórica, c.a. 51.

79 Al descuido del rey por mantener las antiguas etiquetas achacaba también el Bureo el desorden en las entradas a la Cámara, con el consiguiente perjuicio para las diferentes jerarquías de la corte: «entran sin diferencia muchas personas hasta aquella pieças que corresponden a distinción de otras gerarquías; cuyo perjuyzio, no sólo es del cargo del Mayordomo Mayor, sino es también de la Dignidad de Cardenales, Potentados, Grandes, Presidentes, Embaxadores, Primogénitos, Generales y Titulos, cuyas classes contenidas dentro del limite politico de sus entradas, o se hallan oy confusas por la inobservancia, o preferidas de otras inferiores», f.6. 
Así pues, el Rey Cristianísmo podía hacerse servir en Versalles y sus otros palacios de recreo como si del mismísimo campo de batalla se tratara, pero nunca se atrevería a imponer igual régimen en las Tullerías. Lo mismo debía de observarse en España: "que las prerrogativas de sus Nobles Guardas pueden practicarse con la soleminidad de acampado, y que son incompatibles con la eco. nomia y policia de las Reales Casas de Corte». Nunca el Palacio, ni tan siquiera en pleno conflicto bélico, debería confundirse con un campamento militar.

\section{LAS REFORMAS DEL ALCÁZAR Y EL NUEVO CEREMONIAL DE 1709}

Pero, de hecho, convertir el viejo Alcázar madrileño -único palacio junto al Buen Retiro que Felipe V habitara de forma continuada hasta 1715- en una magnífica residencia real, más acorde a la concepción y a los gustos de la corte francesa, venía siendo uno de los proyectos más acariciados por el entorno del nuevo monarca, a pesar de los gastos de la guerra, y habría de convertirse en una de tantas empresas en las que la Princesa de los Ursinos derrochara sus energías ${ }^{80}$.

Bajo su atenta dirección, la mayoría de las transformaciones arquitectónicas del Alcázar corrieron a cargo de Teodoro Ardemans, Maestro Mayor de las Obras Reales. Sólo en una fase ya avanzada, el arquitecto Robert de Cotte desde París, y su discípulo René Carlier en Madrid, se encargarían de llevar a cabo nuevas decoraciones al gusto francés. Gracias a los planos del propio Ardemans de 1705 y 1709 , y al de Du Verger de 1711 podemos seguirle las pis. tas a unas obras que se prolongaron aproximadamente hasta 1718 , cuando la iniciativa de crear La Granja desvie la atención y el dinero hacia ese nuevo Real Sitio ${ }^{81}$.

Las reformas llevadas a cabo en el Alcázar durante este periodo obedecieron a dos objetivos diferentes: reacondicionar las habitaciones privadas de los monarcas, adaptándolas a su particular modo de vida, y conferir una nueva dimensión a los espacios públicos, de acuerdo a los nuevos conceptos de representación de la majestad real importados de Francia. Propósitos que no siempre resultaron fáciles de conciliar con total coherencia.

Olvidándonos ahora de los arreglos hechos en los aposentos de la reina para dotarlos de una mayor comodidad, las transformaciones más radicales se llevaron a cabo en los espacios ocupados por el Cuarto del rey, variando enteramente su distribución habitacional. El primero de estos grandes cambios, introducido por Felipe V, parece haber sido el establecimiento de un dormitorio común para ambos soberanos. Este único dormitorio - al que el rey

80 Sobre las reformas del Alcázar madrileño en época de Felipe V: Barberto, J. M., op. cit., págs. 199-2 19; BotTIENAU, Y., op. cit., págs. 291-309 y 692-694; MORAN, M., op. cit., págs. 73-86; SANCHO, J. L. «El interior del alcázar de Madrid durante el reinado de Felipe V», en CHECA, F. (dir.), op. cit., págs. 96-111.

${ }_{81}$ Callejo Delgado, M. ${ }^{a}$ J., El Real sitio de San Ildefonso, Ed. Universidad Complutense, 3 vols., Madrid, 1988.

Hispania, LV1/3, núm. 194 (1996) 965-1005 
ya nunca renunciará-- se ubicó a comienzos del reinado en la Sala de las Furias que, por su proximidad al Cuarto de la reina, habia sido utilizada a menudo para pernoctar por los monarcas de la dinastía anterior. Delante de ésta, y ya dentro del Salón de Comedias, se había levantado una Antecámara, denominada por Ardemans en 1705 como «Pieza nueva de los Gabinetes", entre cuyos usos debió figurar, precisamente, la reunión de los diversos Consejo de Gabinete que durante los primeros años auxiliaran al soberano en el gobiemo de la Monarquía ${ }^{82}$. A continuación, la Pieza del Cancel, erigida con carácter provisional en tiempos de Carlos II, permitía el acceso directo de los reyes a la tribuna de la capilla.

A finales de 1705 , los soberanos decidieron trasladar su dormitorio hasta la Pieza de los Gabinetes, dejando en cambio la Sala de las Furias como gabinete privado. En los años siguientes, se acabó instalando un dormitorio de protocolo para el rey -nunca utilizado- a la entrada del Salón de las Comedias, destinando el resto de la pieza -que perdía así todo su carácter público- como salón para uso de "sus Majestades en particular" ". De este modo, en la crujía interior del ala principal del palacio, en una serie de habitaciones oscuras, orientadas al norte y abiertas al interior de Ios patios, quedaban instalados los nuevos apartamentos privados para uso conjunto de ambos soberanos, rompiendo la tradicional separación entre los cuartó del rey y de la reina. Las habitaciones reales, ahora más aisladas y protegidas, cedían, sin embargo, para otros usos los mejores espacios del antiguo Cuarto del rey.

Éstos, tal y como señalara Barbeito, quedaron reservados para las nuevas salas de representación y aparato: «entendiendo que constituyen el marco más apropiado para acoger la presencia del rey en medio de sus cortesanos» ${ }^{84}$. La nueva distribución supondrá, entonces, la demolición de la mayoría de las habitaciones privadas de los monarcas de la Casa de Austria - abiertas, como hemos visto, en un régimen muy estricto a las diferentes jerarquías de cortesanos--, siendo sustituidas por una larga hilera de antecámaras y de salones públicos extendidos desde la antigua Piexa de la Antecámara hasta el Salón de los Espejos.

Para llevar a cabo estas transformaciones fue precisa una intensa modificación de la estructura habitacional del Alcázar de Carlos II. En el ala oeste, la primera modificación realizada fue la creación de una nueva Pieza de Ias Audiencias, resultante de unir la antigua Cámara con la Antecamarilla de los Embajadores. A partir de aquí, en la crujía interior, se abrían dos grandes Antecámaras que desembocaban en la Pieza Obscura, realizadas a costa de derribar todo el pequeño laberinto de piezas y pasillos que antes ocu-

82 Escudero, J. A., Los orígenes del consejo de Ministros en España, Madrid, 1979, t.l., págs. $31-54$

83 Así se le denomina en el plano de Du Verger de 1711, reproducido por BotTINEAU, Y., op. cit., págs. 692-694.

84 Barbeito, J. M., op. cit., pág. 212. 
paran el comedor de noche del rey, los servicios de aparador, guardarropa, etc. Al tiempo, en la crujía exterior, el magnífico espacio de la Galería Dorada, se destinó ahora a la construcción de cinco pequeñas alcobas para el Padre Confesor, la Furriera, el Guardarropa, la Secretaría de la Cámara y el Barbero de corps ${ }^{85}$.

Como prolongación de la anterior enfilada de antecamaras, la Galería de los Grandes, ampliada a costa de tres pequeñas alcobas colindantes, se convirtió en el Salón Nuevo o de los Grandes que comunicaba con la Pieza Ochavada y el Salón de los Espejos. Estas tres piezas, desplegadas a lo largo de la crujía exterior de la fachada principal y destinadas a funciones públicas, constituían la culminación de una secuencia ininterrumpida de espacios representativos -magníficamente decorados- que, dando la vuelta a más de medio edificio, se extendía desde el acceso por la Sala de Guardias hasta el trono colocado ahora en la pared del fondo del Salón de los Espejos, rematando la última perspectiva.

La reformas parecian, entonces, encaminadas fundamentalmente, a dotar al edificio de una serie de salones de aparato que, a imitación de Versalles, permitieran brillar con todo su esplendor la vida cortesana, entendida en unos términos de ampulosidad escenográfica desconocidos hasta entonces en Madrid. Tal y como señalara Miguel Morán, la felicitación enviada por el duque de Borgoña a su hermano con motivo de estas obras - "me alegro (...) de que vuestro súbditos puedan veros en vuestra capital de una manera adecuada a vuestra dignidad"-, resulta sobradamente expresiva con respecto a su finalidad: "se trata, pues, de presentar, de hacer ver al rey de forma conveniente, cambiando de arriba abajo la estructura de un palacio que estaba concebido para proteger y ocultar al soberano de las miradas indiscretas" ${ }^{86}$.

Desde luego, las transformaciones arquitectónicas del Alcázar abrían la posibilidad de que en la corte madrileña se pudieran llegar a establecer costumbres semejantes a las que imperaban en el Versalles de Luis XIV. Pero, a cambio de tanta magnificencia palaciega, el rey quedaba ahora mejor protegido que nunca en sus habitaciones privadas y en las de la reina, indiferente si lo deseaba a los requirimientos de las etiquetas. $Y$ podría optar o no por hacerse visible ante la corte según su voluntad.

Desde luego, con la nueva disposición de las habitaciones reales lo que resultaba imposible de todo punto de mantener era el antiguo régimen de entradas a la Cámara del rey, que era ahora preciso regular nuevamente ${ }^{87}$.

Coincidiendo con el inicio de la remodelación del Alcázar, en enero de 1709 se dictaron los reales decretos que daban nueva "regla y forma" a las

85 El Barbero de Corps, sus Ayudas y el Peluquero habian tenido su «aposentillo» durante el reinado de Carlos II en la Pieza Ochavada, donde debían esperar a ser llamados para el aseo del rey, A.G.P., Luis I, c.'. 3 .

86 MORÁN, M., op. cit., págs. 15-16.

87 Visto el caos reinante en la vida de Palacio, el duque de Benavente venía pidiendo al rey desde 1708 que se convocara una junta especial, semejante a la de 1647, para llevar a cabo una revisión general de las etiquetas de palacio, A. G. P., Felipe V, leg. 322.

Hispania, LV]/3, núm. 194 (1996) 965-1005 
entradas a la Cámara y cuarto del rey. Según éstos, por la mañana se abriría la puerta del Salón de los Espejos, contiguo al dormitorio real, permitiendo el acceso de primera entrada a los Jefes de ambas casas reales, los Capitanes y el Sargento Mayor de las Guardias de Corps, los Grandes, los Gentileshombres de Cámara de ejercicio y entrada, los Consejeros de Estado, los Ministros del Gabinete ${ }^{88}$, el Confesor, el Capellán Mayor, los dos Secretarios del Despacho ${ }^{89}$, los Coroneles de las Guardias de Infantería, los criados de precisa asistencia para servir y vestir al rey, y "las otras personas con quienes yo quisiere hacer esta distinción". Sentándose el rey en su silla para vestirse, "y no antes", se brindaba el acceso hasta la pieza, en una segunda entrada, a los Mayordomos, los Títulos de Castilla, los Ministros extranjeros, los Ministros de los Tribunales y otros "hombres conocidos".

A las demás horas de día, tendrían el acceso libre hasta este mismo Salón todos lo que disfrutaban de la primera entrada, así como los Mayordomos y Primeros Caballerizos, y, por la noche, desnudándose el rey, se admitiría de nuevo al grupo de la segunda entrada.

Volviendo a la rutina de por las mañanas, acabando el soberano de rezar y entrando en el cuarto de la reina, los cortesanos debían despejar el Salón de los Espejos, quedando únicamente en él los Ministros del Gabinete, los Gentileshombres de Cámara, los Jefes de la Casa, el Capitán de Guardia de servicio, el Mayordomo semanero, el Primer caballerizo y los Coroneles de las Guardias, «todos éstos para que, cuando yo salga al Despacho pueda darles la orden para por la tarde».

Los subalternos de las Guardias, Casa y Caballeriza debían esperar las ordenes de sus jefes en la Pieza Ochavada, «en la cual y en las demás que estan antes de ella, se podrán detener los que han salido de la de los Espejos, y todos los demás hombres conocidos".

Las puertas del dormitorio real deberían estar siempre cerradas, permitiéndose el acceso únicamente a los que tuvieran llave, y volviendo a cerrarse tras su paso.

El acceso por el cuerpo de Guardias, permanecería asimismo rigurosamente vigilado, cuidando de "no dejar entrar a mi Cuarto sujeto alguno indecente, permitiéndose esto sólo en los días de Audiencia y en las Comidas en puiblicos ${ }^{90}$.

El nuevo decreto de entradas y el ceremonial que establecía no podían ser más ajenos a los usos tradicionales del Alcázar. Aún respetando algunas pecu-

88 Además del embajador francés, Amelot, componian aquel año el Consejo de Gabinete, los duques de Medinasidonia, Veragua, San Juan, Montellano, el marqués de Bedmar, el conde de Frigiliana y don Francisco Ronquillo, SAN FELIPE, Marqués de, op. cit., pág. 168.

89 Los dos Secretarios del Despacho eran entonces José Grimaldo, para guerra y hacienda, y el marqués de Mejorada para los restantes asuntos (Escudero, J. A. , op. cit., I, págs. 40-45). Su inclusión en este ceremonial no dejaba đe ser una importante novedad, ya que hasta entonces los Secretarios del Despacho Universal, aún teniendo un estrecho y cotidiano contacto con el monarca, constituian una figura prácticamente invisible en el ceremonial público de palacio.

${ }^{90}$ A. G. P., Histórica, c. ${ }^{0} 49$ y 55; Luis I, c. ${ }^{3}$ 3, y Felipe V, leg. 313. 
liaridades de la corte madrileña, intentaba ser una fiel imitación del lever y el coucher de Luis XIV, tan célebres en la vida de Versalles ${ }^{91}$. Los cortesanos, privados de su acceso selectivo a las distintas piezas del cuarto del rey, se veían ahora invitados a asistir, sin apenas diferencias de rango, a unas ceremonias que convertían los actos más privados de la vida del monarca en un continuo espectáculo público. Concluídas éstas, y cumplido su encuentro con la corte, el rey se consideraba en su derecho de retirarse en privado el resto de la jornada, sin que ninguna etiqueta pudiera impedírselo.

\section{EX REY SE ESCONDE}

¿Qué vigencia tuvo el ceremonial establecido en 1709? No resulta fácil resolver este interrogante, pero todos los indicios apuntan hacia un escaso cumplimiento.

Cierto que su promulgación coincidió con el inicio de unas obras que, transformando drásticamente el aspecto de la planta principal del Alcázar, harían variar también en profundidad la mecánica de la vida diaria que transcurría entre sus habitaciones. Durante los meses sucesivos a su promulgación, el decreto de entradas fue ampliándose para incluir a aquellos individuos a quienes el rey pretendía favorecer con el acceso al Salón de los Espejos ${ }^{92}$. La princesa de los Ursinos, animadora incansable de la vida de palacio, continuó ejerciendo su papel de gran maestro de ceremonias, y supo aprovechar los nuevos vientos de adhesión al rey que soplaban entre la nobleza desde la crisis de $1709^{93}$. Pero después de la muerte de Maria Gabriela de Saboya, y tras la salida de España de la que fuera su Camarera Mayor, los acontecimientos parecen tomar un rumbo muy distinto.

El fallecimiento de la reina en febrero de 1714 determinó al rey a abandonar Madrid y a retirarse al palacio de los duques de Madinaceli en Guadalajara durante casi un año. Para el tiempo que duró el encierro se establecío un nuevo régimen de entradas que no modificaba demasiado el decreto de 1709. A la pieza inmediata en donde el rey dormía tenían acceso los grandes y sus primogénitos, los oficiales de palacio con «llave de entrada», los Embajadores, los Capitanes Generales, los Ministros del Gabinete, el Patriarca de Indias, los Mayordomos, los Caballeros del Toison, quienes tuvieran tratamiento de grandes, el Sargento Mayor de las Guardias de Corps y los Tenientes Generales ${ }^{94}$. A la pieza siguiente al cuerpo de guardia podría entrar toda la demás "gente conocida" ${ }^{95}$. Durante gran parte de su retiro, sin embargo, el monarca

91 SOLnON, Jean Françios, La Cour de France, París, 1987, págs. 315-337; BURKE, P., op. cit., págs. 87-91; APOSTOLIDÉs, J., Le Roi-machine:spectacle et politique au temps de Louis XIV, París, 1981,

92 A. G. P., Histórica, c. ${ }^{2} .49$ y 55.

93 BotTINEAU, Y., op. cit., págs. 209-210, y A. G. P. Histórica, c.. 51.

94 Por orden «a boca» de el monarca esta entrada fue ampliada para el representante de Baviera, el Abad Gonzaga y el Marqués Gonzaga.

95 A. G. P., Histórica, c. ${ }^{3} 49$ y 55; Luis I c... 3 y Administrativa, leg. 623.

Hispania, LVI/3, núm. 194 (1996) 965-1005 
eludió los compromisos oficiales y, como solía, se rodeó únicamente de los servidores de confianza, incluida la princesa de los Ursinos, ahora Aya de los infantes 96

La vuelta de Felipe $\mathrm{V}$ con su nueva esposa al palacio madrileño del Buen Retiro sumergío a los jefes de la casa real en el desconcierto acerca de qué reglamento se debia observar entonces para regular las entradas al cuarto del rey. Se les respondió que el mismo que había estado vigente en Guadalajara ${ }^{97}$, pero ante la imposibilidad de aplicarlo al tropel de cortesanos que acudían al palacio sin conocer perfectamente sus prerrogativas, el marqués de Montealegre - que gobernaba la Cámara interinamente desde la muerte del duque de Benavente en 1709- pidió que se colocara un ujier bajo sus órdenes a las puertas del dormitorio real para "que sólo permita la entrada a las personas que S.M. tiene nominadas, sin que se introduzcan los que no la tienen" ${ }^{98}$.

$\mathrm{Al}$ año siguiente, el Alcázar volvió a ser habitado por la pareja real y el marqués de Montealegre pidió una vez más instrucciones sobre la materia. Esta vez, el rey consideró que "en esto no hay que hacer, ni providencia que dar; estas entradas deben ser las mismas que eran en este Palacio antes que yo me asuentase de ét, y según el reglamento que antecedentemente habia dado para ellas, observándose, como haréis se observe, lo mismo en cuanto a eston" ${ }^{99}$.

Pero aunque el ceremonial de 1709 se mantenía sobre la letra, su práctica diaria, en cambio, parece mucho más dudosa. Desaparecida de escena la princesa de los Ursinos, con ella desaparece también el impulso y el aliento por mantener en Madrid, alrededor del soberano, una auténtica vida cortesana al gran estilo de Versalles. El propio Felipe V, educado lejos de la corte de su abuelo, estaba poco familiarizado con la mecánica que regulaba las jornadas de Luis XIV. Sus aparatosas puestas en escena delante de la corte exigian, desde luego, unas cualidades humanas y personales de las que el monarca español parece haber estado escasamente dotado. El trato a diario con los cortesanos, a la vez distante y cordial, implicaba una seguridad y unas dosis de autocontrol que casi siempre escaparon al dominio de Felipe V. Si algo llamaba la atención en la persona del nieto de Luis XIV desde su acceso al trono español fue, precisamente, su escaso gusto por la representación. Sus crisis mentales - sus famosos «vapores»-, cada vez más frecuentes y más graves, le sumergirán en el más profundo aislamiento, haciéndole del todo odioso el trato con los extraños.

Cuando en 1722 el duque de Saint-Simon visite la corte española como embajador extraordinario de Francia, reparará en el aspecto físico de Felipe $\mathrm{V}$ que recuerda al de su abuelo. Reconocerá que en funciones públicas y ceremonias solemnes el rey "habla y se conduce con una majestad y una exacta corrección que sorprenden", para aclarar a continuación el motivo de esa

96 Danvila, A., El reinado relámpago. Luis I y Luisa Isabel de Orleâns, Madrid, 1952, pág. 64.

97 A. G. P., Administrativa, leg. 623; Felipe V, leg. 316; Luis I, c. . 3 y 4.

98 A. G. P., Histórica, c. 55; Felipe $V$, leg. 336.

99 A. G. P., Administrativa, leg. $623 ;$ Luis $l, c^{2} .4$.

Hixpunia, LVl/3, num. 194 (1996) 965-1005 
sorpresa: "por lo mismo que distan de lo ordinario». La tónica habitual, más bien, es el hosco aislamiento en que discurre la vida diaria del monarca ${ }^{100}$.

Según Saint-Simon, este riguroso aislamiento - «que llega hasta la reconcentración - databa sólo de los últimos años y había estado inspirado por Alberoni y ejecutado por la reina, mero instrumento del favorito "para anular a los consejos y para aislar al rey hasta el extremo en que se encuentra, sin permitir que hasta el llegase nadie» ${ }^{101 .}$

La situación de Alberoni en palacio durante su privanza debió resultar realmente complicada, a juzgar por algunos testimonios que nos han legado 102. Personaje ajeno a la corte y a la administración españolas, Alberoni tuvo que enfrentarse a la oposición de una gran parte de la nobleza y contar con la hostilidad de los oficiales de la Casa Real que, aprovechando sus cargos y dignidades, podían obstaculizar su acercamiento a los monarcas ${ }^{103}$. Para soslayar este inconveniente fue necesario continuar suprimiendo gradualmente los usos tradicionales de la vida de palacio y enfrentarse con los altos cargos para liquidar sus prerrogativas. Sus esfuerzos para sacar de Madrid al confesor del rey, el padre Daubenton, o a los ayos del los Príncipes, el cardenal Giudice o el duque de Populi, son sólo algunos ejemplos ${ }^{104}$. Su Memorial pidiendo la reforma de las casas reales en 1718, no obedece, si tenemos en cuenta la situación política de la corte, tanto a un deseo de racionalización y economías, como a la necesidad de hacer barrer cargos y diginidades de ella, entre otros, al Sumiller de Corps ${ }^{105}$. El famoso apaleamiento sufrido por Alberoni delante de los soberanos y a manos del Mayordomo Mayor, el marqués de Villena, a quien el cardenal, forcejeando, pretendía impedir el acceso al dormitorio del rey, constituye no sólo una sabrosa anécdota, sino ante todo, un magnífico ejemplo de la lucha entre cortesanos para defender su control del acceso a la persona del rey durante aquel periodo ${ }^{106}$.

Caido en desgracia Alberoni, el monarca se resisitirá, a pesar de los intentos de la reina, a bandonar su aislamiento. Y el desorden y la confusión, a juicio del duque de Saint-Simón reinaban en el palacio:

\footnotetext{
100 SaINT-Simon, Duque de, Cuadro..., págs. 13-16.

101 Ibidem. pág. 16.

102 Sobre la orientación exterior de la política de Alberoni siguen siendo útiles las obras clásicas de Bourgeors, E., La diplomatie secrète au xvm siècle. II: Le secret des Famèse. Philippe V et la politique d'Alberoni, París, 1909 y Lettres intimes de J. M. Alberoni au compte Rocca, París, 1892.

103 Del caos administrativo de época de Alberoni, a caballo entre el valimiento y la via reservada, proporciona abundantes noticias el marqués de San Felipe, detallando el desconcierto de oficiales y funcionarios ante el despacho irregular de los papeles: "Este era el desorden nunca visto en la Monarquia, porque los ministros no tenían respuesta de oficio, y vivian con la desconfianza de que nada llegaba a oidos del Rey, y aún se hallaban embarazados en el obedecer a quien no era declarado primer ministro ni tenía oficio alguno por donde juridicamente podía mandar", op. cit., págs. 269 y 313.

104 lbidem. págs. 256, 311-314.

105 A. G. P., Administrativa, leg. 340.

106 SAINT-SIMON, op. cit., págs. 113-114.
} 
"Las famosas Etiquetas de España, que eran alli reglas inexcusables del mecanismo de todas las cosas, han sufrido diversas alteraciones, por grados, siendo por fin enterradas durante la privanza de Alberoni, a quien molestaban, y que no pudieron resucitarse después de su caida, porque el Rey no ha podido cambiar de costumbre ni resolverse a romper el aislamiento a que le redujo este Ministro y que no es contrario a sus gustos. Hay, pues que perder de vista estas diferentes piezas de los aposentos de Palacio, donde todo el mundo era admitido sin ujier $y_{1}$ sin embargo, sin confusión, según su rango o el privilegio de sus entradas; no considerar ya las diversas llaves más que en las casacas adornadas, y la mayor parte de todos los cargos como nombres vanos y emolumentos mediocres, desprovistos de toda función y de todo privilegio; comprender que los pocos que no lo han perdido todo son sólo la sombra de lo que fueron antes; que los más distinguidos señores de todas clases: Grandes, Virreyes, cargos principales, Ministros de primera clase, Prelados preeminentes, Embajadores y la gente común y de escalera abajo, pajes $y$ oficiales, todos están mezclados, sin orden, en los mismos lugares, sin distinción, y en mayor confusión aún que a la que hemos llegado en Francia» ${ }^{107}$.

La vida diaria de los reyes, tal y como nos la relata Saint -Simon, tiene desde luego muy poco que ver con lo que había sido en tiempos el funcionamiento de la Cámara y de la Casa del rey. Felipe V continúa viviendo con su esposa en las mismas habitaciones comunes de su propio cuarto y en las demás piezas del cuarto de la reina, «y, para decirlo todo —-señala Saint-Simon maliciosamente- tienen sus sillas ahujereadas en el mismo sitio" ${ }^{108}$. Rara vez ambos esposos se separan - "sino para actos cortos, raros, indispensables»-, de manera que duermen juntos, comen juntos, reciben juntos en audiencia y se trasladan siempre juntos fuera del palacio.

Al dormitorio común sólo son admitidos, a la hora de despertarse - las ocho de la mañana-, un Ayuda de Cámara francés, Valois, y la poderosa nodriza de la reina, Laura Piscatori. Desayunan juntos y se entretienen en la cama hasta que, a las diez, es llamado el marqués de Grimaldo para despachar con el rey ${ }^{109}$. Acabado el despacho, al mediodía, el rey se traslada a la habitación contigua para vestirse. Nada, entonces, de ceremonial público: alli sólo son admitidos Valois y otros dos criados franceses de servicio, el Secretario de la Cámara, La Roche, y el Jefe del Guardarropa, Hersent ${ }^{110}$. Además de ellos, los dos favoritos del momento: el duque del Arco y el marqués de Santa Cruz, íntimos entre sí y ambos del marqués de Grimaldo. La situación no puede ser más irregular porque a ninguno de ellos, por sus cargos, les corresponde el privilegio de aquella función.

107 Bbidem., págs. 22-23.

108 Ibidem., pág. 23.

109 El despacho regular con Grimaldo, desde la caída de Alberoni, representó, según J. A. Escudero, una vuelta a las normas del estilo antiguo administrativo, op. cit., l, pág. 60.

110 Entre los franceses que acompañaran a Felipe $\mathrm{V}$ a España continúa por estas fechas manteniendo su privanza también el marqués de Valouse, nombrado primero Mayordomo y luego Primer Caballerizo. Pese al escándalo que su carrera suscitaba en la corte, Saint-Simón aseguraba que mantenía "una asiduidad cerca del rey a toda prueba», op. cit., págs. 227-229. 
El duque del Arco, a quien el rey tenía que agradecer que le hubiera salvado en un accidente de caza de la embestida de un jabalí, es su Caballerizo y Montero Mayor, y gobernador de la mayoría de los Reales Sitios. Como claro favorito del monarca, cuenta Saint-Simon, es el único admitido en el interior de palacio "aún en las horas más secretas». Los reyes le llaman familiarmente, don Alonso, y había conseguido resistir sin graves percances la privanza de Alberoni. Su llave de Gentilhombre de Cámara le ha permitido usurpar las funciones del Sumiller de Corps y "llevar solo todo el servicio" "'.

En sus ausencias, pocas, es susitituído por el marqués de Santa-Cruz, Mayordomo Mayor de la reina, Gentilhombre de Cámara del rey, y el otro claro favorito de los soberanos. "Durante el dia -cuenta Saint-Simon-, gozan de privanza y de favor, pero en nada se asemejan a las del Sumiller, que no han pasado a nadie, lo mismo que su autoridad. El Rey es quien representa en esto el cargo" $" \mathrm{t}$.

De hecho, la sumillería de corps llevaba vacante desde la muerte del duque de Benavente en 1709. En teoría, el gobiemo interino de la Cámara había recaIdo en el Gentilhombre más antiguo, el marqués de Montealegre, a quien en vísperas de su fallecimiento, Saint-Simón retrataba "retirado por estar enfermo y muy disgustado por no desempeñar su cargon ${ }^{113}$. Le sucedería en 1722 el conde de Peñaranda, pero con las mismas limitaciones prácticas en el servicio cotidiano del rey ${ }^{114}$. Saint-Simon explicaba así el proceso de imparable decadencia en que había caído el cargo más ambicionado de la corte española: «(el sueldo) es todo lo que le queda ahora a este cargo, que no conserva ya ni funciones, ni entradas, autoridad ni servicio, lo mismo que si se tratase del personaje más extraño a la Corte de España. La Princesa de los Ursinos tuvo sus razones para desposeerle de todo cuanto pudo; el cardenal Alberoni hizo lo demás y la costumbre que de él tomó el Rey confirmó definitivamente la anulación del cargo" ${ }^{115}$.

La irregularidad en el servicio personal del monarca no podía menos que continuar sembrando el descontento y la preocupación entre los oficiales de la Casa del Rey - cada día más desplazados por los criados de la Casa de la Reina-- y, en especial, entre los de la Cámara. En ocasiones este disgusto se manifiesta abiertamente, como en la siguiente consulta que el Veedor y Contador de la Cámara dirigió al marqués de Montealegre a comienzos de 1721:

"El norte de la Cámara y sus individuos han sido las Etiquetas que para el Real servicio se hicieron. La inobservancia de ellas vuestra excelencia tiene muy presente, $y$ cosidero a vuestra excelencia (con su tolerancia) muy mortificado, $y$ mucho más que siendo vuestra excelencia el Jefe para remediarlo, esté el puesto de Sumiller de Corps tan desatendido que no se le permita corregir los desórdenes que se experimentan, asi en el cuarto del Rey nuestro señor, como en el del Principe

111 lbidem. págs. 67-69.

112 Ibidem., págs. 230.

113 lbidem. págs. 98-99.

114 Ibidem., pág. 105.

115 Ibidem., págs. 229-230.

Hispania, LVI/3, núm. 194 (1996) 965-1005 
nuestro señor, habiéndose vulnerado las órdenes que su Majestad se sirvió dar para reglar las entradas y que cada uno se contuviera hasta donde le permitia su empleo, dando a cada tuno en el suyo la mayor autoridad. Esto está enteramente adulterado, y con más relajación que antes, pero pues su Majestad (que lo tendrá presente) lo permite, debemos creer ser de su Real agrado en servirse como se sirve, sin aquella autoridad regia correspondiente a su real persona" 116.

Pero lo que los oficiales de palacio y la corte toda debían echar de menos, a aquellas alturas, no debía ser tanto el antiguo ceremonial de los Habsburgo, para muchos olvidado, sino la no sustitución de aquellas viejas etiquetas y ceremonias por otras que regularan la vida de palacio y otorgaran la magnificencia y majestad requerida al soberano y a quienes le rodeaban. Poco quedaba ya en 1722 de las apariciones públicas del rey ante su corte reglamentadas en 1709. Al parecer, el Salón de los Espejos continuaba abriéndose todas las mañanas para los visitantes, pero el rey sólo se asomaba a él, por una puerta entreabierta, para dar las órdenes del día a los oficjales de la guardia de corps. Pocos eran entonces los que acudían a las horas del «cortejo», si no estaban interesasados en conseguir una audiencia particular por algún motivo ${ }^{117}$. Si había audiencia pública o capilla, podía verse al rey, a la ida y a la vuelta, atravesar los salones y "se le puede hablar entonces sin audien cia, aunque sin comodidad, por la rapidez, más bien la velocidad, con que anda (...) Nadie osaba hablar, ni de paso, a los anteriores reyes de España; el Rey de hoy lo sufre; pero su paso es tan rápido, que a menos de no tener que decirle más que monositabos, es imposible hablarles "118. Cuando no había funciones públicas, sólo vislumbraban al monarca quienes estaban próximos a la puerta por donde asomaba, «y aquellas mañanas va menos gente a Palacio; hay pocos asiduos en total y menos habituales" ${ }^{119}$. Iguales y mermadas oportunidades existían de dirigir la palabra al rey cuando salía de caza por la tarde - "aunque por lo incómodo de la hora hay alli poca gente»-o a su vuelta - «casi siempre de noche»-. El resto del tiempo, Felipe V y su esposa, permanecían encerrados en privado en sus habitaciones, servidos únicamente por las damas de la reina y los pocos personajes que ya hemos mencionado ${ }^{120}$.

Sin embargo, todavía a estas alturas del reinado, cuando reside en el Alcá. zar, Felipe $\mathrm{V}$ mantiene aún la costumbre de conceder audiencias públicas $\mathrm{y}$, en ocasiones precisas y señaladas, se recibe a toda la corte, bien para celebrar capillas, besamanos o, de vez en cuando, algún baile. En esas contadas oportunidades «la corte es nutrida, magnifica y tiene todo el esplendor de la de un gran Rey, ${ }^{221}$.

116 A. G. P., Administrativa, leg. 371.

117 Saint-Simon da a entender la retirada progresiva de la nobjeza del palacio en vista del tono de la vida de la corte: «pues la mayor parte de los señores no van nunca alli (Buen Retiro), hi tampoco a Palacio, y algunos nada, ni siquiera a las funciones", op. cit., pág. 37.

118 lbidem., págs. 25 y 232 .

119 Ibidem., págs. 25.

120 lbidem., págs. 26-31.

12. Ibidem. págs. 37-43. 
Desde el final de la guerra, el desahogo de la hacienda ha permitido a los reyes, además, comenzar a realizar jornadas, arreglar sus palacios -en especial San Ildefonso-, y pasar en Madrid únicamente el periodo que transcurre desde primeros de diciembre hasta Semana Santa. Durante las jornadas de Aranjuez, El Escorial o Balsaín la vida del rey cambia poco, y viaja con un reducidísimo cortejo: el marqués de Grimaldo y sus oficiales de la Secretaría, el embajador francés -en aquellas épocas en que la gran política europea todavía distrae al rey de su ensimismamiento-, y unos cuantos criados inferiores imprescindibles. En Aranjuez o El Escorial es posible ver al rey y al ministro "como en Madrid", pero en Balsaín todo son dificultades para romper la intimidad con que transcurre la vida cotidiana ${ }^{\mathrm{t} 22}$. Cada vez el rey se retrae más de su vida pública, de sus obligaciones de representación, de los negocios, en fin, de la Monarquía, y los cortesanos han de mirar al Príncipe de Asturias como única esperanza de su supervivencia.

Obsesionados por justificar la abdicación de Felipe V, optando entre la prosecución de la santidad o del trono de Francia ${ }^{123}$, los historiadores han prestado escasa atención al carácter ambiguo y transaccional que presenta en muchas de sus facetas la situación legada por el monarca a su hijo en 1724. Para comenzar, no cabe duda de que la corte de San Ildefonso nunca pensó en perder completamente las riendas del gobierno de la Monarquía. El Consejo de Gabinete instituido para Luis I y el dispositivo ideado con el tándem Grimaldo-Orendain constituyen la más palpable demostración de este hecho ${ }^{124}$. ¿No fue entonces el retiro de los reyes a San Ildefonso un paso más para alejar a Felipe V del palacio y de los cortesanos, dejando en Madrid un rey marioneta que, antes de hacerse con con las tareas de gobierno, desempeñara, en cambio, las obligaciones de representación de la majestad real que tanto repugnaban a su progenitor? El retrato de Felipe V como urey y no rey", hecho en aquellos días por el embajador francés, apunta en esta dirección.

Rodeado de sus más íntimos y fieles servidores Felipe $\mathrm{V}$ abandonaba la corte en enero de $1724{ }^{125}$, permitiendo con ello que en palacio se abrieran nuevos y prometederos horizontes. Y una de las primeras ambiciones de la nobleza cortesana fue, precismanete, la de restablecer el antiguo ceremonial real, tratando de suprimir las novedades introducidas en las últimas

122 Ibidem., págs. 46-48.

123 Abundante bibliografia sobre esta vieja cuestión en HiDALGo, Jacinto, «La abdicación de Felipe $V_{m}$, en Hispania, XXII (1962), págs. 559-589.

124 Escudero, J. A., op. cit., I, págs. 63-73. En el Archivo de Palacio se conserva buena parte de la correspondencia sostenida por el marqués de Grimaldo con sus corresponsales en las demás cortes europeas durante el reinado de Luis I, A.G.P., Felipe V, leg. 300; Luis 1, c. ${ }^{2}$. 15.

125 En un memorandum dirigido a Felipe $V$ por el marqués de Grimaldo acerca de la organización de la casa que habría de servirle en San lldefonso se apunta el siguiente requisito: «he comprendido que el deseo de V.M. es de no servirse de Grandes en su retiro, ni tener en él los empleos de los Jefes como hasta aqui, y apartarse de todo lo que ficera etiquetas y formalidades", A. G. P., Histórica, c.". 126.

Hispania, LV/3, nùm. 194 (1996) 965-1005 
décadas ${ }^{126}$. Aunque en el Archivo de Palacio han quedado escasas noticias acerca de la reorganización del servicio del nuevo soberano, algunos indicios documentales no dejan lugar a dudas. Para comenzar, la Cámara real volvió a contar con un Sumiller de Corps que la dirigiera, el marqués de Altamira, a quien Danvila retrata como «echando muy de menos las etiquetas suprimidas» ${ }^{127}$. Por iniciativa suya, durante los primeros meses de 1724, se elaboraron en la Secretaría de la Cámara varios expedientes acerca de las antiguas etiquetas y, en particular, acerca del ceremonial de entradas en el cuarto del rey ${ }^{128}$. Aunque los expedientes quedaran sin resolver por la muerte prematura del soberano, sí debieron introducirse cambios importantes, ya que Felipe $\mathrm{V}$ al retomar la corona advirtí́ explícitamente que deseaba "ser servido en la misma forma que hasta aqui, y no como se servía el rey su hijo, que santa gloria haya” 129.

¿Qué otro sentido que restablecer el respeto a las etiquetas austriacas y al viejo orden tiene si no el curioso episodio del encierro de la reina niña? ${ }^{130}$. Al referirse a él el marqués de San Felipe, tras hacer una alabanza de las etiquetas españolas - «tan aborrecidas de las otras naciones, acostumbradas a no vivir con tanta circunspección»-, justificaba los hechos advirtiendo que eran intolerables las pretensiones de libertad de la joven soberana "que no comprendia los incovenientes de aflojar ni declinar de aquel alto decoro y sostenimiento que compete a la Majestad" 131.

Por ello la oposición levantada por la vuelta de Felipe V no fue sino una manifestación del descontento de la nobleza, del "partido español " ya perfectamente constituido, y, en particular de los grandes, a quienes Luis I afavorecía en el exterior mucho más que su padre " ${ }^{132}$. La frustración por la muerte del joven monarca, convirtirá durante muchos años al nuevo príncipe de Asturias, don Fernando, en ídolo y esperanza de la oposición aristocrática, aglutinada ahora entorno a su cuarto ${ }^{133}$

Por lo que respecta a Felipe V, su situación personal y la de su entorno fue empeorando con el paso del tiempo. La gravísima crisis de 1727 le alejó más que nunca antes de toda cuestion de gobierno --entregado ahora por completo a la reina-, aislándole en el mutismo más absoluto ${ }^{134}$. La Jornada de Andalucía, ideada por la reina con la excusa de aliviarle, tampoco produjo los

\footnotetext{
126 Danvila, A., op. cit., pág. 262.

127 lbidem. pág. 243.

128 A. G. P., Luis I, c.. 3 y 4.

129 A. G. P., Felipe V, leg. 315 .

130 Danvila, A., op. cit., págs. 239-319.

13! SAN Felipe, Marqués de, op. cit., págs. 359-360.

132 Ibidem, pág. 361.

133 EGido, T., Opinión pública y oposición al poder en la España del siglo xvill (/7/3-/759), Univ. Valladolid, 1971, págs. 281-295.

134 DEL CAMpo RASO, J., Memorias políticas y militares para servir de continuación a los Comentarios del marqués de San Felipe, Madrid, B. A. E., t. XCIX, 1957 (Edic. C. Seco Serrano),
} pág. 424.

Hispania, LVI3, núm. 194 (1996) 965-1005 
resultados esperados ${ }^{135} \mathrm{y}$, en 1730 , viviendo en el alcázar sevillano, el proceso de locura del rey parecia irreversible. Descuidando su aspecto e higiene personal hasta un grado insólito, inaccesible a todos excepto a su familia, Felipe $\mathrm{V}$ comenzó entonces a invertir su horario, trastocando la noche en día y el día en noche ${ }^{136}$. De esta época data la hegemonfa gubernamental de Patiño, sostenida a dura penas gracias a la tenacidad del ministro para soportar los desplantes del monarca y ganarse la voluntad de la reina ${ }^{137}$.

La vuelta del rey a Madrid, y la aparente superación de los peores momentos de su enfermedad, no hicieron variar mucho el encierro y la ya casi absoluta invisibilidad de la persona real. Su permanente melancolía, la absurda programación de sus jornadas, su alejamiento de los negocios quedaron sobradamente plasmados en las sátiras, pasquines y hojas volanderas que inundaron la corte en los últimos años del reinado ${ }^{138}$.

De hecho, durante las dos postreras décadas de su vida, Felipe V logró que la corte prescindiera casi absolutamente de su persona. Si comparamos la rutina de sus jornadas descrita en una relación anónima de comienzos del reinado de Fernando VI ${ }^{139}$ con la que hiciera Saint-Simon en 1722, la concluisión a ojos vista es que la vida pública del monarca se ha deteriorado notablemente:

"...aunque el régimen no era el más regular en las horas, ya por la costumbre no se hacía en ello novedad, y se sabia que la cena era a las 5 horas de la mañana, con las ventanas cerradas; que a las 7 se iba a la cama, y que a las doce tomaba una susbtancia. Regularmente, a la una hora después del mediodía se vestia, a las 3 horas oía misa en la pieza inmediata. Concluido el santo sacrificio de la misa, admitía en la conversación, en la cual era más frecuente el embajador de Francia, como también el conde de Montijo, Mayordomo actual de la reina, y el marqués de San Juan, Sumiller de Corps del Rey.

En este modo o régimen de vida, después de la comida no tomaba siesta, sino que se estaba en el cuarto gastando un rato a la ventana, otro divirtiéndose con los relojes, algún reto leyendo o haciéndose leer un libro, y así en esto y en otras cosas indiferentes pasaba el tiempo hasta entrada más la noche, que se le tenía alguna diversión de música o representación; a las dos horas después de medianoche lla-

135 Ya en las primeras semanas del viaje, algunas ciudades se quejarían por la inasistencia del rey a las fiestas preparadas en su honor, CEBRIÁN GARCiA, J., La sátira política en 1729. Repercusiones literarias del viaje de Felipe $V$ al reino de Sevilla, Jerez, 1982, págs. 91-92. Sobre el desarrollo de la jornada JuRAdo SÁNCHEZ, J., «Los viajes reales en la Edad Modema: la visita de Felipe V y su corte a Badajoz y Andaluciam, en Andalucia Moderna. Actas del II Congreso de H. ${ }^{a}$ de Andalucía (Córdoba, 1991), t. III, Córdoba, 1995, págs. 541-558.

136 Detalles sobre la asombrosa conducta monarca durante 1731-32 en DANVILA, A., Estudios del siglo xvıl español. Fernando VI y doña Bárbara de Braganza, 1713-48, Madrid, 1905; más reciente el estudio de Márquez Redondo, A. G., Sevilla "Ciudad y Cone» (1729-1733), Sevilla, 1994.

137 Escudero, J. A., op. cit, págs. 89-98; ver asimismo CAMPo RASO, J. del, op. cit., pág. 506.

138 EGIDO, T., op. cit., págs. 110-114; 159-170.

139 Epitome de la vida y costumbres, muerte y entierro de el Catholico Monarca Don Felipe Quinto..., B.N.M., mss, 10.818/30.

Hispania, LV1/3, nùm. 194 (1996) 965-1005 
maba a los secretarios para el despacho, y en esta manera el tiempo hacia su círculo, habiendo entrado en este género de vida desde el año de 1733 que de Sevilla se vino a Madrid" 140.

Cada día más grueso y torpe de movimientos ${ }^{141}$, hacía años que Felipe $\mathrm{V}$ había abandonado su pasión por la caza, que ya no paracticaba, y "vivta contento sin salir del cuarto, más que para ir algunas veces a Nuestra Señora de Atocha a la tribuna de la iglesia» ${ }^{142}$. Fuera de Madrid, con séquitos cada vez más reducidos ${ }^{143}$, la rutina se modificaba escasamente, y ni siquiera los hermosos parques de Aranjuez conseguían hacer salir al rey de su habitación ${ }^{144}$.

En este proceso de progresiva invisibilidad debió colaborar la destrucción del Alcázar en madrileño en 1734, quedando ya sólo el Buen Retiro para solemnidades públicas. Pero también este tipo de actos se celebraban cada vez menos. La audiencias públicas dejaron de tener lugar, lo que suponía que sus vasallos no podían ya ver libremente al rey en palacio, en uno de los pocos actos que lo permitían ${ }^{145}$. Incluso, al cuerpo diplomático se le hizo prescindir de sus entradas públicas en la corte, siendo recibidos por el monarca, en el mejor de los casos, con una total informalidad ${ }^{146}$. Tal y como conclúa una sátira escrita por entonces, parecía como si ya sólo por medio de un ejercicio de fe los españoles pudieran creer tener rey ${ }^{147}$.

\section{CONCLUSIÓN}

A la luz de todo lo expuesto, la evolución del ceremonial palatino durante el reinado de Felipe V y de la institución que lo sustentaba, la Casa Real, presenta caracteres bastante ambiguos. Desde luego, constituyó una ocasión perdida para reformar en profundidad el entramado de las antiguas Casas Reales y el ceremonial hispano-borgoñón heredado de los Austrias, tal y como deseaba su abuelo. Cierto que la delicada situación política de los primeros años aconsejaba prudencia antes que nada, pero en el entorno del

140 Ibidem., f. $3 \mathrm{r}-\mathrm{v}$.

141 Vease la descripción de] rey hecha por Noailles en 1746, recogida por CoXE, W, op. cit., III, pág. 192 .

142 Epítome..., f. 4r.

143 A. G. P., Felipe V, legs. 317-319.

144 Epitome..., f. $7 \mathrm{v}$.

145 Ibidem., f. $20 \mathrm{r}-\mathrm{v}$. La vuelta a la celebración de audiencias públicas era uno de los gestos que se esperaban a comienzos del reinado de Fernando VI, Papel que dio al Rey Nro.Sr. Dn. Fernando el 6." un Leal Basallo suyo, en el primer Año de su Reynado, en que le demuestra el Estado en que se halla la Monarquia, B. N. M., mss. 10.902

146 Libro de Audiencias de Ministros Extranjeros, A. G. P., Registros, núm. 256, f. Ir- $\psi$.

147 Egldo, T., op. cit., pág. 110. 
monarca se respiraba un decidido afán de reformas en la corte que, de haberse proseguido con perseverancia, hubiera desembocado, probablemente, en una situación más parecida a la de los reinados de sus sucesores que a la bastante absurda del último Felipe V.

El monarca prefirió, en cambio, inhibirse de casi todo aquello que imcurnbía a las obligaciones más pesadas y onerosas del ceremonial real, y apartarse de las persistentes demandas de sus cortesanos que ansiaban compartir con él la gloria de su majestad y los beneficios de su gracia. Pero ni su retiro tuvo el carácter laborioso del de Felipe II, ni su apartamiento de las antiguas reglas ceremoniales implicó una profunda renovación de la vida cortesana al estilo de Luis XIV. Difícilmente el Rey Sol hubiera podido imaginar un retiro y una invisibilidad mayores para el monarca católico que las que su nieto aspiró a imponerse a sí mismo.

Abandonada prácticamente por el soberano, que prescindió en buna parte de sus servicios y de la presencia de sus oficiales - desviando así la atención de los cortesanos hacia las casas de la reina y de los príncipes de Asturias-, la Casa del Rey acabó girando torpemente sobre sí misma, tratando de asegurar su superviviencia institucional y financiera. Las continuas luchas entre sus altos oficiales, por motivos de rango y jurisdicción, y el marasmo económico son algunos de los rasgos dominantes que presentaba la Casa del Rey a finales de la década de 1740, cuando el marqués de la Ensenada se haga cargo de reformar los servicos de palacio ${ }^{148}$.

Al contrario que su padre, Fernando VI no pudo resistir ya la presión para que se restaurara en torno a su persona una auténtica vida cortesana. El restablecimiento de las Audiencias públicas, de las fiestas y de la vida social de la corte corrí, entonces, pareja con la reforma que Ensenada llevara a cabo en las Casas Reales en 1748.

Cabe preguntarse, sin embargo, si el abandono compulsivo y enfermizo de Felipe $\mathrm{V}$ de las viejas etiquetas no fue, al fin y a la postre, un paso más en el proceso de su reforma. Pocas disposiciones vinieron a sustituir de forma efectiva -como sucediera con el ceremonial de entradas de 1709- las antiguas reglas del ceremonial hispano-borgoñón. Ello implicó, a corto plazo, la desafección política de la nobleza respecto a la dinastía y un más que probable deterioro de la imagen real. Pero, a cambio, implicó otras ventajas: a fuerza de no ser observados, algunos usos antiguos fueron olvidados, o acabaron siendo aplicados por individuos que ignoraban gran parte de sus detalles y de su significación ritual ${ }^{149}$. Cuando Carlos III regule su vida en palacio y la mecánica de su corte, nadie le recordará ya la necesidad de observar el estilo de los reyes de la Casa de Austria. Más acorde con los tiempos y con las sensibilidades, sustituyendo el ceremonial de alcoba por el de comedor, Carlos III recibirá a diario a la corte en un preciso ritual cuya organización tomaba

\footnotetext{
148 Preparo actualmente sobre esta cuestín un estudio con el profesor J. Sánchez Belén.

149 Vid. VARELA, J., La muerte del rey. El ceremonial funerario de la Monarquía española (1500-/885), Madrid, 1990, págs. 146-153.
} 
ETIQUETA Y CEREMONIAL PALATINO DURANTE EL REINADO DE FELIPE V IO0

muchos elementos prestados del ceremonial de entradas de 1709 150. Pero, al contrario que su padre, Carlos III sí cumplirá meticulosamente sus obligaciones sociales con los cortesanos "lo cual era tanto más difícil —alababa su biógrafo- que siendo (a) diario, parece no tendría qué decirles» ${ }^{151}$.

150 A. G. P., Administrativa, leg. 623; Histórica, c. ‥ 55.

151 Fernán NúṄez, Conde de, Vida de Carlos $I I$, (Ed. A. Morel Fatio y A. Paz y Meliá), Madrid, 1988 (ed, facsímil).

Hispania, LVI/3, มúrn. 194 (1996) 905-1005 